OPEN ACCESS

Edited by:

Annette Gilchrist,

Midwestern University, United States

Reviewed by:

Xuehua Xu,

National Institute of Allergy and

Infectious Diseases (NIH),

United States

Paula H. Stern,

Northwestern University,

United States

*Correspondence:

Jian Luo

jluo@tongji.edu.cn

Ning Wang

n.wang@sheffield.ac.uk

Mingyao Liu

myliu@bio.ecnu.edu.cn

Specialty section:

This article was submitted to

Bone Research,

a section of the journal

Frontiers in Endocrinology

Received: 04 November 2021

Accepted: 15 December 2021

Published: 28 January 2022

Citation:

Wang F, Liu M, Wang N and Luo J (2022) G Protein-Coupled Receptors in Osteoarthritis.

Front. Endocrinol. 12:808835. doi: 10.3389/fendo.2021.808835

\section{G Protein-Coupled Receptors in Osteoarthritis}

\author{
Fanhua Wang ${ }^{1}$, Mingyao Liu $^{2 *}$, Ning Wang ${ }^{3 *}$ and Jian Luo ${ }^{1,2 *}$ \\ 1 Yangzhi Rehabilitation Hospital (Shanghai Sunshine Rehabilitation Center), Tongji University School of Medicine, \\ Shanghai, China, ${ }^{2}$ Shanghai Key Laboratory of Regulatory Biology, Institute of Biomedical Sciences and School of Life \\ Sciences, East China Normal University, Shanghai, China, ${ }^{3}$ Department of Oncology and Metabolism, The University of \\ Sheffield, Sheffield, United Kingdom
}

Osteoarthritis $(\mathrm{OA})$ is the most common chronic joint disease characterized, for which there are no available therapies being able to modify the progression of $O A$ and prevent long-term disability. Critical roles of G-protein coupled receptors (GPCRs) have been established in OA cartilage degeneration, subchondral bone sclerosis and chronic pain. In this review, we describe the pathophysiological processes targeted by GPCRs in OA, along with related preclinical model and/or clinical trial data. We review examples of GPCRs which may offer attractive therapeutic strategies for OA, including receptors for cannabinoids, hormones, prostaglandins, fatty acids, adenosines, chemokines, and discuss the main challenges for developing these therapies.

Keywords: osteoarthritis, G protein-coupled receptors, clinical trials, cartilage degradation, OA pain

\section{INTRODUCTION}

Osteoarthritis $(\mathrm{OA})$ is the most common degenerative joint disease and one of the leading causes of chronic disability in elderly (1). As a joint degenerative disease, it is characterized by chronic pain, restricted mobility and loss of joint function, increasingly causing a substantial financial burden to society and decreasing quality of life for patients (2). Although OA was primarily thought to be driven by cartilage metabolism disorders, other pathological processes including osteophyte formation, imbalanced subchondral bone remodeling and synovial inflammation are found to form a vicious cycle that contributes to OA progression (Figure 1) $(3,4)$.

Multiple cells, including chondrocytes, osteocytes, osteoclasts, osteoblasts, endothelial cells and sensory neurons, all contribute to this progression (5-7). Early during the cycle, changes first occur in cartilage, including the disruption of chondrocytes pericellular matrix and increased metabolic activity of chondrocytes. As the disease progresses, microscopic cracks are observed in the superficial zone of the articular cartilage, and subchondral bone plate becomes thinner and more porous. With further disease progression, erosion of extracellular matrix (ECM) and increased senescent chondrocytes lead to the development of deep fissures. In the subchondral microenvironment, in response to abnormal mechanical loading and pro-inflammatory mediators, osteocytes upregulate the ratio of RANKL/OPG and osteoclasts are activated resulting in bone resorption and active angiogenesis. In late-stage OA, cartilage chondrocyte death is evident and calcified cartilage expands into the superficial zone of articular cartilage. In addition to the development of subchondral bone cysts, growing sensory innervation and vascular invasion from subchondral bone into cartilage, and osteophyte formation also occur. 


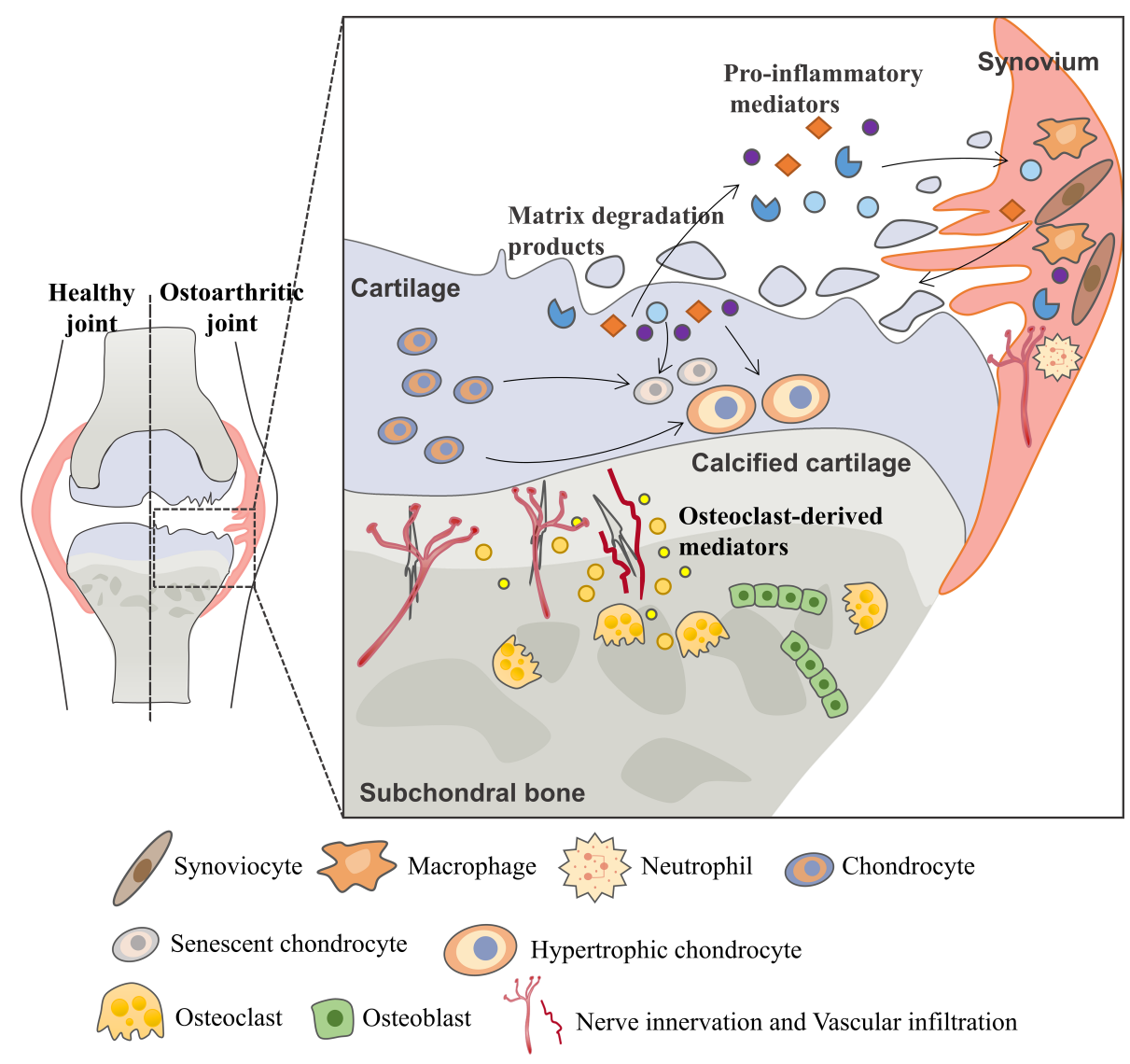

FIGURE 1 | Vicious cycle during OA progression. During the osteoarthritis process, the imbalance between the anabolic activities and catabolic activities of cartilage ECM-degrading enzymes (aggrecanases and matrix metalloproteinases) leads to further extracellular matrix degradation. Products from matrix degradation act on the synovium to induce inflammation and the release of pro-inflammatory mediators (cytokines, chemokines, etc.) that feedback on chondrocyte and cause cartilage breakdown. This process also promotes phenotypic alterations of chondrocytes and leads to chondrocytes hypertrophy and senescence. In the subchondral bone, osteoclasts are activated in response to abnormal mechanical loading and pro-inflammatory mediators, resulting in bone resorption and release of osteoclast-derived mediators which regulate sensory innervation and vascular invasion into the osteochondral junction. This process also correlates with OA pain. Abnormal bone remodeling is then followed by increased bone formation, leading to subchondral bone sclerosis. The homeostatic imbalance of the osteochondral unit increases cartilage susceptibility to disruption and contributes to OA pathological processes.

Patients with OA experience pain and disability, for which there are predominantly palliative options, such as pain management with analgesics/anti-inflammatory medication and intra-articular injections of corticosteroids (8-10). No current pharmacological therapy is able to exhibit convincing disease-modifying efficacy and prevent long-term disability. Developments in the understanding of OA pathophysiology have enabled the identification of a variety of potential therapeutic targets involved in OA pain, synovial inflammation or structure alteration. Emerging putative disease-modifying OA drugs (DMOADs) hold promise for OA management by regulating cartilage anabolic or catabolic processes, subchondral bone remodeling or synovial inflammation (6, 11). However, the clinical benefit of OA treatments is uncertain as most clinical trials of DMOADs fail to rescue the pathophysiological changes in $\mathrm{OA}$, in addition to the challenges caused by the long follow-up period of clinical trials in developing DMOADs. Therefore, novel OA management strategies are urgently needed.

G protein-coupled receptors (GPCRs), receptors with seven transmembrane domains, comprise the largest and most diverse family of integral membrane proteins that participate in different physiological processes, such as neurotransmission, hormone release, heart contractility and immune responses (12). Based on structural similarities, GPCRs are divided into 6 major families. Only four families are present in humans, including class A (rhodopsinlike) family, class B (secretin) family, class C (metabotropic glutamate-like) and class F (frizzled/smoothened) family. Among them, class A is the largest family with approximately 670 receptors $(13,14)$. GPCRs couple extracellular stimuli to intracellular responses via two main signal transduction mechanisms: heterotrimeric $G$ proteinsdependent and -independent. $G$ proteins are heterotrimeric guanine nucleotide binding proteins that consist of $G \alpha, G \beta$ 
and $\mathrm{G} \gamma$ subunits $(15,16)$. The coupling specificity and downstream regulation of GPCRs are largely driven by $\mathrm{G} \alpha$ -subunits, which are classified as Gs, Gi/o, Gq and $\mathrm{G}_{12 / 13}$ according to their functions. $G \beta$ and $G \gamma$ subunits form a constitutive heterodimer that binds reversibly to the $\mathrm{G} \alpha$ subunit. After activation of GPCRs, G $\beta \gamma$ subunits are released to trigger the activation of downstream effect signaling pathways. These free subunits are competent to interact with the downstream enzymes or channels to drive second messenger generation and modulate cell physiology $(17,18)$. Once G proteins are released, the protein kinase family of G-protein coupled receptor kinases (GRKs) phosphorylate the intracellular region, after which the phosphorylated GPCRs recruit $\beta$ arrestins. This leads to the desensitization and internalization of GPCRs, thereby playing the role of "closing" signal, as a negative feedback of $\mathrm{G}$ protein-dependent GPCR signaling. In addition, MAPK and PI3K/Akt signals can be activated by $\beta$ arrestins or the Gq pathway, indicating that there is potential crosstalk between heterotrimeric $G$ protein-dependent and independent signaling pathways $(19,20)$.

GPCRs are important targets for drug discovery largely owing to the wide range of physiological and pathophysiological processes in which GPCR targeting can have a major impact. To date, approximately 500 approved drugs target GPCRs, which accounts for almost $30 \%$ of all drugs approved by $\operatorname{FDA}(14,19)$. Although most GPCR-targeted drugs are for metabolic diseases, cancers, neurodegenerative diseases and others (21-23), it has been reported that several different types of GPCRs are important for regulating OA symptoms including cartilage degeneration, subchondral bone sclerosis and chronic pain (Figure 2). In this review, we'll review current understanding of these GPCRs' physiological roles and mechanistic involvements in $\mathrm{OA}$, and discuss emerging therapeutic targets that show promise in preclinical models of OA and/or in clinical trials.

\section{CANNABINOID RECEPTORS}

Over the past decade, the endocannabinoid system has emerged as a potential target for OA therapy with evidence of its involvement in cartilage destruction and $\mathrm{OA}$ pain. Cannabinoids target cannabinoid receptors 1 and 2 (CB1 and CB2), two GPCRs originally identified as classical cannabinoid receptors $(24,25)$. Both cannabinoid receptors have been suggested to be expressed in arthritis tissues including OA cartilage, subchondral bone and synovial tissue (26-28). It has been extensively demonstrated that natural cannabinoids have anti-inflammatory properties and can protect cartilage from degradation during $\mathrm{OA}(26,29,30)$. ACEA, a CB1 agonist, suppresses interleukin 1 beta (IL-1 $\beta$ )-induced senescence in human primary chondrocytes (31). In a surgical mouse model of $\mathrm{OA}$, the $\mathrm{CB} 2$ receptor has been shown to regulate susceptibility to OA. The study revealed that genetic ablation

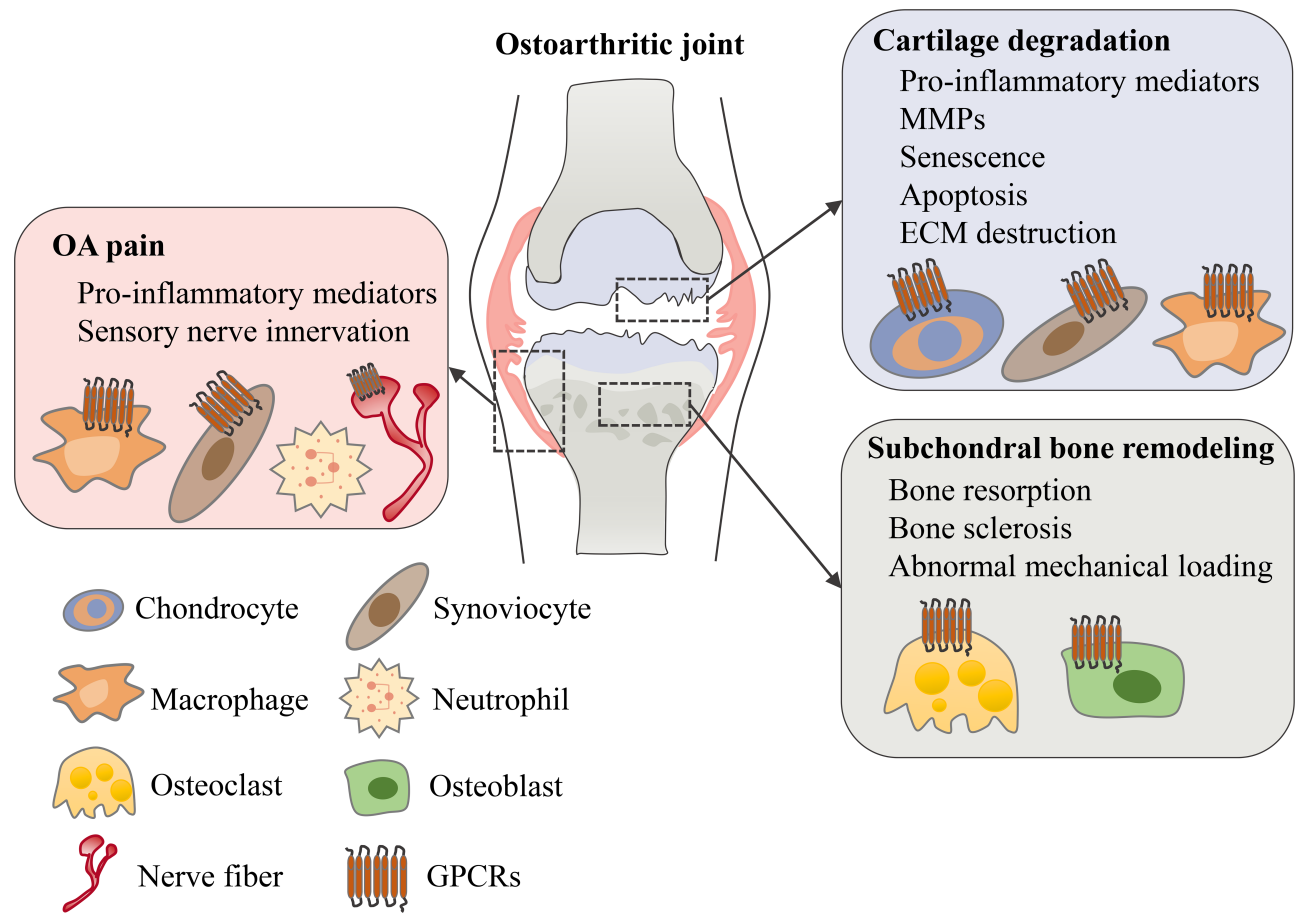

FIGURE 2 The role of GPCRs in osteoarthritis. In an osteoarthritic joint, GPCRs are expressed in different tissues and cell types. Various types of GPCRs mediate and regulate OA symptoms including cartilage degeneration, subchondral bone remodeling and OA pain. 
of CB2 aggravated OA pathogenesis compared to wild-type OA mice (32). Additionally, CB2 depleted chondrocytes produced less proteoglycans in vitro. Moreover, HU-308 (CB2 agonist) and WIN55212-2 (synthetic cannabinoids) prevented cartilage degradation, while WIN55212-2 was also found to inhibit the activity of an aggrecanase, a disintegrin and metalloproteinase with thrombospondin motifs-4 (ADAMTS-4) (31). These studies suggest that the endocannabinoid system protects against cartilage degradation.

Furthermore, endocannabinoids and their receptors have been reported in osteoblasts, osteoclasts and osteocytes (3335). CB1 regulates bone growth during skeletal development, while $\mathrm{CB} 2$ plays an important role in maintaining the balance between bone resorption and bone formation $(36,37)$. Knockout of CB2 led to accelerated age-related osteoporosis in mice, while CB1 knockout mice expressed less nuclear factor kappa B ligand (RANKL), suggesting their possible roles in bone remodeling processes during $\mathrm{OA}(38,39)$. $\mathrm{CB} 1$ and $\mathrm{CB} 2$ receptors are located in synovial tissue where they are expressed on nerve endings that innervate the knee $(38,40)$. In a monoiodoacetate (MIA) model, an OA model that intra-articular injection of sodium monoiodoacetate induces chondrocyte cell death in the articular cartilage, $\mathrm{OA}$ pain and articular structural changes $(41,42)$, agonists of CB1 (ACEA) and CB2 (JWH133 and A796260) all decreased pain behavior or subchondral bone degeneration (43-45). However, current clinical trials targeting the endocannabinoid system in OA gave inconclusive results. A randomized clinical trial in OA patients of PF-04457845, a potent FAAH (fatty acid amide hydrolase with a prominent role in the hydrolysis of endocannabinoids) inhibitor, indicated no significant difference in analgesia compared to placebo (NCT00981357) (46). In another on-going phase II study (NCT03098563), patients with knee OA are being treated with combinations of cannabinoids, benzodiazepines, and opioids for evaluating changes in pain ratings and sensitivity but no results have been published yet.

\section{CHEMOKINES AND RECEPTORS}

Chemokines and their $\mathrm{G}$ protein-coupled receptors control the migratory patterns, positioning and cellular interactions of immune cells, and also induce the recruitment of immune cells into the organs. High levels of chemokines have been observed in rheumatoid arthritis (RA), systemic lupus erythematosus (SLE) and idiopathic inflammatory myopathies (IIM), which are systemic autoimmune disorders $(47,48)$. Many studies have also found that chemokine system is involved in the process of $\mathrm{OA}$. In this section, we summarize the pathogenic functions of chemokines and their receptors in OA, and discuss their potentials as therapeutic targets.

CXC motif chemokine ligand 12 (CXCL12), also known as SDF-1, is recognized as a homeostatic cytokine. SDF-1 and its receptor C-X-C motif chemokine receptor 4 (CXCR4) and CXCR7 play multiple regulatory roles. SDF-1 is involved in the regulation of cartilage tissue homeostasis and can also regulate chondrocyte proliferation, survival, differentiation (49-51).
SDF-1 was shown to negatively regulate mesenchymal stem cell (MSC) chondrogenesis, but the effects of SDF-1 on chondrocyte proliferation and death varied in different studies. CXCR4 and CXCR7, both expressed by chondrocytes, regulate homeostatic and pathological processes during the progression of OA. The upregulated CXCL12/CXCR7 signaling aggravated joint destruction in mice. SDF-1/CXCR4 induced chondrocyte hypertrophy during endochondral bone formation, and the induction of hypertrophic chondrocyte markers, including Runt-related transcription factor 2 (RUNX2), Collagen type X (COLX), and matrix metalloproteinase 13 (MMP13) in chondrocytes, required the presence and interaction of both SDF-1 and CXCR4 (52). During ECM degradation in OA, SDF-1/CXCR4-mediated upregulation of aggrecanase occurred via activation of the nuclear factor $-\kappa \mathrm{B}(\mathrm{NF}-\kappa \mathrm{B})$, mitogenactivated protein kinase (MAPK), and $\mathrm{Wnt} / \beta$-catenin in chondrocytes (53). Moreover, SDF-1/CXCR4 regulates the crosstalk between subchondral bone and articular cartilage in OA pathogenesis (54). Subchondral bone deterioration and excessive bone resorption were aggravated by increased SDF-1 in anterior cruciate ligament-transection (ACLT) mice. SDF-1 from subchondral bone binds to CXCR4 in chondrocytes and induces articular cartilage degradation by promoting shift of TGF- $\beta$ receptor 1 (T $\beta$ RI) signal transduction from activin receptor-like kinase 5 (ALK5) to ALK1. The impact of TGF- $\beta$ on cartilage is anabolic through ALK5 while catabolic through ALK1 $(55,56)$. Indeed, AMD3100, a specific inhibitor of SDF-1/ CXCR4 axis, attenuated $\mathrm{OA}$ by stabilizing subchondral bone microarchitecture and protecting the integrity of cartilage. In addition, studies have demonstrated that TN14003, another antagonist of CXCR4, was more effective in inhibiting release of matrix-degrading enzymes, such as MMP3, MMP9 and MMP13, and in preventing collagen type II (COL2a1) and aggrecan (ACAN) degradation (57, 58). Mechanistically, FGFR3 inhibits CXCR7 expression and CXCL12-dependent macrophage chemotaxis through regulating the $\mathrm{NF}-\kappa \mathrm{B}$ pathways. FGFR3 deficiency in myeloid cells results in more severe joint destruction and synovitis in the destabilization of the medial meniscus (DMM)-induced mouse OA model and in aging mice, whilst blocking CXCR7 in FGFR3 deficiency mice relieved joint destruction of age-related/DMM-induced arthritis (59). Thus, SDF-1 (as CXCL12) plays an important role in the development of $\mathrm{OA}$ and further preclinical and clinical studies are warranted to investigate the feasibility of therapeutically targeting SDF-1/CXCR4/CXCR7 signaling to treat OA.

Other CXCRs may also be involved in the development of OA. For example, even though $\mathrm{CXCR} 2^{-/-}$mice do not spontaneously develop arthritis, the blockade of CXCR1/2 signaling led to decreased ECM production and increased chondrocyte apoptosis. These pathological changes result in the loss of phenotypic stability in chondrocytes and promote OA-like phenotypic alternations $(60,61)$. CXCR3 protein level was also significantly increased in OA patients while knockdown of CXCR3 receptor attenuated chondrocyte apoptosis induced by sodium nitroprusside (62). In the collagenase-induced osteoarthritis (CIOA) model, neutrophils and NK cells were 
showed to be increased in the synovium as disease-promoting immune cells. The CXCL10/CXCR3 axis promoted the accumulation of NK cells and macrophages in the OA joint, whereas $\mathrm{CXCR}^{-/-}$mice failed to develop CIOA (63).

C-C chemokine receptor type 5 (CCR5), the receptor for C-C motif chemokine ligand 4 (CCL4) and CCL5, is expressed in normal chondrocytes but at elevated levels in OA chondrocytes. Cartilage degeneration was markedly reduced in $\mathrm{CCR} 5^{-/-}$mice affected by post-traumatic OA, while mild changes appeared in osteophyte formation and synovitis compared to wild-types (64). These phenotypes suggest that CCR5 plays a selective role in joint damage.

In the bone microenvironment, CCL2, a key regulator mainly expressed by osteoblasts, promotes subsequent recruitment and migration of mononuclear cells via binding to CCR2 (65). Additionally, CCL2 stimulation enhanced the apoptosis of OA chondrocytes while intra-articular injection of CCL2 in mouse knees induced cartilage degradation (66). This result suggests that CCL2/CCR2 axis is involved in cartilage destruction. Further studies showed that $\mathrm{CCR} 2^{+}$macrophages were abundant in OA synovium and in association with articular cartilage tissues. Receded OA pathogenesis is accompanied with lessened local macrophage numbers in CCR2- knockout mice. Pharmacological intervention by RS-504393, a CCR2 antagonist, effectively diminished $\mathrm{OA}$ disease progression in part by reducing synovial macrophage accumulation (67). In conclusion, disruption of CCL2/CCR2 signaling contributes to reduced macrophage accumulation, synovitis and cartilage breakdown in murine OA models.

Intriguingly, chemokine receptors are critical regulators of neurodegenerative conditions and synapse activity, contributing to pain management. In mice, intra-articular/peripheral tissues injections of CXC chemokines induced pain-like behaviors (68). CCL2/CCR2 signaling was upregulated in the joint innervating dorsal root ganglion. This result was clearly associated with movement-provoked pain behaviors after disease induction. Macrophage infiltration and movement-provoked pain behaviors were not developed in CCR2-null mice. However, CCR2-null mice had similar severe allodynia and structural knee joint damage. These results suggested that targeting the CCL2/CCR2 axis will have clinical benefits for OA pain (69-71). A placebo-controlled, Phase II trial testing PF-04136309 (the specific CCR2 antagonist) for OA pain has been completed but the results are as yet unknown (NCT00689273).

Evidence from pre-clinical studies suggests that the development of more effective inhibitors of chemokine receptors has attractive therapeutic potential in treating OA. It should also be noted that numerous chemokines and their receptors are involved in OA pathogenesis, thus targeting the relevant multiple receptors might be needed for therapeutic benefits.

\section{METABOLITE-SENSING GPCRs}

The main metabolite-sensing GPCRs bind metabolites derived from common foodstuffs, including long-chain fatty acids
(LCFAs), medium-chain fatty acids (MCFAs), short-chain fatty acids (SCFAs), bile acid, and various others. It has been reported that free fatty acids (FFAs) contribute to skeletal health, as increasing the supplementation of long-chain polyunsaturated fatty acids (LCPUFAs) positively contributes to joint health and prevents osteoporosis (72-74). LCPUFAs are essential factors to support cartilage homeostasis. Studies have revealed that longchain $\omega-3$ fatty acids reduced secretion or expression of inflammatory cytokines and matrix-degrading enzymes involved in cartilage degradation, such as collagenases or aggrecan-degrading enzymes (aggrecanases). SCFAs augmented systemic bone mass by protecting from bone resorption and suppressing inflammation in chondrocytes $(75,76)$. In this section, we introduce the metabolite-sensing GPCRs involved, biological relevance between metabolism and osteoarthritis, and highlight the beneficial effects of nutritional protection.

Five GPCRs, including GPR40, GPR41, GPR43, GPR84 and GPR120, have been reported to be activated by FFAs. Among which, GPR40 and GPR120 are receptors for LCFAs, GPR41 and GPR43 for SCFAs, while GPR84 for MCFA. OA progression in the knee joint instability-induced OA model was aggravated in GPR $40^{-/-}$mice, and GPR40 $0^{-/-}$chondrocytes secreted more inflammatory mediators and decreased anabolism upon IL-1 $\beta$ treatment (77). In contrast, GW9508, a GPR40 agonist, blocked degeneration of type II collagen and aggrecan by attenuating the expression of matrix-degrading enzymes and pro-inflammatory cytokines in vitro (78). GPR120 $0^{-1-}$ mice displayed an accelerated progression of ACLT surgery-induced OA (79). GPR120 agonists, GW9508 and TUG891, prevented IL-1 $\beta$-induced reduction of ECM through SRY (sex-determining region Y)related HMG (high mobility group) box 9 (SOX9) mediated expression of collagen II and aggrecan in ATDC5 chondrocytes (80). In our previous research, we found that MCFAs receptor GPR84 signaling safeguarded cartilage homeostasis. Activating GPR84 by 6-OAU (agonist) or lauric acid (natural ligand) resulted in increased expression of ECM-related genes in chondrocytes and protected human $\mathrm{OA}$ explants against degeneration (81). SCFAs receptors, such as GPR43, were also shown to be involved in chondrocyte homeostasis. Butyrate, a SCFA produced through microbial fermentation in gut, decreased the inflammatory response in IL-1 $\beta$-stimulated chondrocytes, including reduced expression of proinflammatory mediators (cyclooxygenases 2, nitric oxide synthase 2, IL-6), pro-inflammatory adipokines (lipocalin-2 and nesfatin-1), and adhesion molecule (Vascular cell adhesion molecule 1 and Intercellular adhesion molecule 1). Importantly, the anti-inflammatory activities of butyrate were completely dampened by GPR43 silencing (82).

TGR5, a bile acid-sensing GPCR expressed in cultured chondrocytes, showed reduced expression in response to IL$1 \beta /$ tumor necrosis factor alpha $(\mathrm{TNF} \alpha)$-stimulation in chondrocytes or OA patient chondrocytes. Furthermore, activation of TGR5 using the specific synthetic agonist, INT777 , significantly decreased IL-1 $\beta$ induced senescence and rescued $\mathrm{TNF} \alpha$-induced decreased expression of ECM-related genes in SW1353 cell $(83,84)$. 
These studies of metabolite-sensing GPCRs provide intriguing links between the fields of nutrition, metabolism and $\mathrm{OA}$, which provide insights that nutrient intervention may become new approaches for OA treatment or prevention. The main drawback of research in metabolite-sensing GPCRs and $\mathrm{OA}$ is the insufficiency of translational studies using animal models and related clinical trials.

\section{ADENOSINE RECEPTORS}

Adenosine is a catabolite of ATP and can act as a physiological regulator. Adenosine binds and activates four adenosine receptor subtypes (A1, A2A, A2B, and A3), which are all GPCRs $(85,86)$. In bone homeostasis, adenosine receptor-mediated mechanisms are involved in bone fracture and repair, and response to loading $(87,88)$. Articular chondrocytes in humans express primarily A2A receptor (A2AR) and $\mathrm{A} 2 \mathrm{~B}$ receptor (A2BR) subtypes (89). When cartilage has an aging phenotype or cartilage homeostasis is destroyed, the extracellular ATP will decrease, leading to a decrease in the content of adenosine. Subsequently, the reduction of extracellular adenosine concentration increases the release of chondrocyte-damaging molecules. These molecules include nitric oxide (NO), prostaglandin E2 (PGE2), MMPs, ECM fragments, which further contribute to the cartilage destruction and the pathogenesis of OA $(90,91)$. Observations in mice deficient of A2AR and ecto-5' nucleotidase (an enzyme that converts extracellular AMP to adenosine) showed consistent results of developing spontaneous OA. In contrast, intra-articular injection of adenosine prevented development of OA and restored the cartilage homeostasis by engaging A2AR in rats (92). This could be due to the fact that the exogenous adenosine activates $\mathrm{A} 2 \mathrm{AR}$ and regulates the pathogenesis of $\mathrm{OA}$ via suppressing the expression of a variety of pro-inflammatory cytokines, such as NO, PGE2, IL-1 and TNF. The anti-inflammatory role of A2AR has indeed been proposed in mouse articular chondrocytes treated with hyaluronan oligosaccharides or collagen-induced arthritis (CIA) $(93,94)$. In addition, studies have shown that A2AR stimulation enhances mitochondrial metabolism and prevents mitochondrial injury. Intra-articular injections of a liposomal A2AR agonist improved the reactive oxygen species (ROS) burden, proteoglycan catabolism and chondrocyte viability in knee cartilage of obesity-induced OA mice (95). Moreover, polydeoxyribonucleotides (PDRNs), deoxyribonucleotide polymer chains with 50-2000 base pairs in length, can counter proteoglycan degradation in cartilage explants by decelerating the activity of MMPs (96) and can also activate A2AR to decrease cytokine production and reduce cartilage erosion of collageninduced arthritis (97). There have been multiple randomized, double-blind clinical trials comparing the efficacy of intraarticular polynucleotides and hyaluronic acid injections in treating knee osteoarthritis. Results suggested that Knee Society Score total score (KOOS) and pain items were statistically significantly ameliorated in both polynucleotides- and hyaluronic acid-supplemented groups, with higher efficacy in the polynucleotides group. Additionally, polynucleotides led to significant symptomatic relief as measured by the KOOS after only 2 weeks of treatment, while similar improvements with administration of hyaluronic acid were seen after 18 weeks (98-101).

Other adenosine receptor subtypes have also been suggested to have potential roles in OA. The A2BR has been associated with chondrogenic differentiation. A2BR agonists suppressed hMSC chondrogenic differentiation through downregulating the expressions of ECM-related genes and cartilaginous transcription factors, while antagonists of A2BR induced chondrogenic differentiation of hMSC (102). Ablation of A3R led to development of $\mathrm{OA}$ in aged mice. A3R selective agonists protected cartilage by downregulating intracellular CaMKII kinase and RUNX2 transcription factor (103). CF101, a highly selective, synthetic agonist to the A3R, can induce apoptosis of inflammatory cells, and prevent cartilage damage and bone destruction in rat knee osteoarthritis (104). It is worth noting that excessive adenosine supplement to body is not advisable, as children lacking adenosine deaminase develop chondrodysplasia, with plasma adenosine levels increasing to the micromolar level $(105,106)$. In summary, the adenosine receptor is an important homeostatic regulator of cartilage homeostasis, cartilaginous inflammation and $\mathrm{OA}$ progression. Therefore, adenosine supplement may represent a novel approach for OA treatment.

\section{PROTEASE-ACTIVATED RECEPTOR}

Proteinase-activated receptors (PARs) constitute a unique family of GPCRs that are widely expressed by fibroblast-like cells, chondrocytes and osteoblasts, immune cells in joints as well as in sensory neurons. Proteolytic enzymes signaling via PARs have been implicated in inflammation and pain in RA. For a comprehensive review, please refer to Oikonomopoulou et al., 2018 (107). PAR2 was detected in chondrocytes and synovial tissues from OA patients, while expression of PAR2 in OA chondrocytes was upregulated by IL-1 $\beta / \mathrm{TNF} \alpha(108,109)$. Activation of PAR2 in human OA cartilage upregulated catabolic and pro-inflammatory pathways, resulting in cartilage degradation (110). PAR2 expression was significantly upregulated in articular cartilage in OA mice. Several studies suggested that deletion of PAR2 retarded the OA progression, cartilage damage, and subchondral bone remodeling disequilibrium in OA mouse models (111-113). Additionally, PAR2 has been shown to be expressed in the proliferative/ hypertrophic chondrocytes within osteophytes. PAR2 ${ }^{-/-}$mice presented less osteophyte formation, no osteosclerosis, and reduced pain perception in a DMM model. Intra-articular injection of hPAR2 in $\mathrm{PAR}^{-/-}$mice restored osteophyte formation and cartilage damage to the similar level as in wildtype mice, confirming the pathogenic role of PAR2 in the DMM model (114). Further studies showed that AZ3451, an antagonist of PAR2, prevented the IL-1 $\beta$-induced inflammatory cytokines release, catabolic gene expression, senescence, and apoptosis in chondrocytes. Intra-articular injection of AZ3451 ameliorated cartilage destruction in a rat OA model (115). Therefore, PAR2 
has the potential to orchestrate OA-related pain, cartilage and bone pathology. It is plausible that, through further preclinical and/or clinical verification, targeting proteolytic pathways can bring in benefits to RA or OA patients and reduce joint damage and inflammation.

\section{PROSTAGLANDIN RECEPTORS}

PGE2, the most abundant prostaglandin in most tissues, is generated by the initial actions of the cyclooxygenases on arachidonic acid (116). COX-2-selective non-steroidal antiinflammatory drugs (NSAIDs) reduce pain and inflammation, and are thought to act via inhibiting PGE2 in humans $(117,118)$. The cartilage releases a high level of PGE2, a key proinflammatory and joint pain molecule in OA patients. PGE2 binds to four specific $G$ protein-coupled receptors, prostaglandin E receptor 1-4 (EP1-4). Among them, EP2 and EP4 have been found to be associated with cartilage repair and OA development. Early research showed that simultaneous stimulation of EP2 and EP4 enhanced proteoglycan accumulation and intracellular cyclic adenosine 3',5'-monophosphate (cAMP) production during the differentiation of rat primary chondrocytes (119). The expression patterns of EP2 and EP4 are different during the commitment of MSC to chondrogenesis. EP4 expression continuously increases in this process, while the expression of EP2 increases at the earlier stage and then decreases (120). Other studies showed that growthpromoting and apoptosis-protecting genes were upregulated in human articular chondrocytes treated with EP2 agonists. The culture of rat femurs showed an increase of proliferating cell nuclear antigen (PCNA) staining in chondrocytes, suggesting EP2 enhanced the growth in articular cartilage (121). Gelatin hydrogel containing PLGA microspheres conjugated with ONO-8815Ly, a selective EP2 agonist, promoted tissue regeneration in a rabbit chondral and osteochondral defect model (122), whilst intraarticular injections of EP2 agonist lessened joint pain and promoted tissue repair of osteochondral defect in rabbits (123). Furthermore, an EP2 agonist enhanced reconstruction of the boundary between articular cartilage and subchondral bone, which is imperative to maintain the articular structure. It is interesting to note that the regenerated tissue contained both EP2- and PCNA-positive chondrocytes, indicating that the cartilage regeneration was executed mainly by EP2-positive cells (122). The same research team also found that ONO-8815Ly prevented cartilage degeneration in ACLT and DMM-induced cartilage traumatic models, which was associated with restraining the expression of MMP13, a catabolic factor to matrix network (124). Similarly, another study demonstrated EP2 agonist downregulated MMP13 mRNA expression via the cAMPprotein kinase A pathway in osteoarthritis chondrocytes (125).

A previous report suggested that EP4 was upregulated in OA cartilage. However, effects of EP4 on the cartilage catabolism during OA progression still remain controversial. EP4 antagonist (AH23848) prevented PGE2 induced matrix degradation and MMP13 expression in OA cartilage explants, implicating EP4's pivotal role in mediating the PGE2 catabolic effects during OA progression (126). To the contrary, another study showed that PGE2 inhibited IL-1 $\beta$-induced expression of MMP1 and MMP13 via EP4 by suppressing MKK4-JNK MAPK-c-JUN pathway in human chondrocytes (127). Furthermore, the EP4 receptor mediates the PGE2-elicited inflammation and sensitization of sensory neurons, while EP4 inhibition contributes to the development of targeted therapies for antiinflammatory and analgesic effect in OA (128-131). Grapiprant, an EP4 antagonist, has been approved for by the FDA treating OA pain in dogs $(132,133)$. A multicenter, randomized study demonstrated that the inhibitor of microsomal prostaglandin $\mathrm{E}$ synthase-1 (LYA) but not the EP4 antagonist (LYB) improved clinical signs of OA pain in dogs (134). Although there are animal model studies and clinical applications in effects of EP receptors in $\mathrm{OA}$, the in vivo functions and molecular mechanisms of $\mathrm{EP}$ receptors in cartilage homeostasis and $\mathrm{OA}$ need further investigation. In particular, there is no relevant research using gene-level ablation of EPs to verify their functions in cartilage, while conditional knockout mice should be considered in order to avoid the lethal consequence of genome-wide knockout.

\section{HORMONE RECEPTORS}

Hormone receptor signal transduction, such as for norepinephrine (NE) and epinephrine, plays important roles in articular cartilage homeostasis and OA. In this section, we summarize the relevant research on hormone receptors involved in the cartilage system. $\alpha 2 \mathrm{~A}$ - and $\beta 2$-adrenoreceptor positive chondrocytes were observed in cartilage, with more evidence in the pre-hypertrophic and hypertrophic cartilage. Intercepting $\alpha 2 \mathrm{~A}$-adrenoreceptor increased aggrecan production and decreased MMPs expression in the degraded temporomandibular joint cartilage of rats $(135,136)$. NE reversed IL-1 $\beta$ induced production of IL-8, MMP13, COL2, and glycosaminoglycans, and decreased proliferation in chondrocytes. This was achieved via $\beta$-adrenoreceptor signaling. However, NE was also shown to increase proliferating cells and induce apoptosis via $\alpha 1$ - adrenoreceptor in chondrocytes (137).

The calcitonin receptor was identified in bovine articular cartilage (138). KBP, an agonist of amylin and calcitonin receptors, counteracted DMM induced cartilage erosion, degradation biomarkers and pain behavior in rats (139). Nerves containing the calcitonin gene-related peptide (CGRP) have been implicated in a number of pain scenarios. The CGRP release has been observed in the joints of OA rodents, as perivascular sensory and sympathetic nerve fibers innervate the osteochondral junction in osteoarthritic knees (140-142). Innervation of $\mathrm{CGRP}^{+}$neurons in subchondral bone was significantly augmented after OA induction, whilst blockade of $\mathrm{CGRP}^{+}$sensory fibers innervating in the subchondral bone reduced OA pain $(143,144)$. In addition, antagonizing the CGRP receptor ablated mechanosensitivity of joint nociceptors in MIA and DMM OA rats (145). 
The parathyroid hormone $(\mathrm{PTH}) /$ parathyroid hormonerelated protein $(\mathrm{PTH} / \mathrm{PTHrP})$ receptors are well known for their biologic actions in controlling mineral homeostasis, bone development, and bone remodeling (146-148). Additionally, activation of the PTH/PTHrP receptor slowed the chondrocyte proliferation and delayed chondrocyte hypertrophy $(149,150)$, although other studies showed that PTHR1 is upregulated in OA cartilage $(149,151)$. Importantly, teriparatide (recombinant human PTH), an FDA-approved treatment for osteoporosis, has been shown to decelerate cartilage degeneration and induce matrix regeneration in post-traumatic osteoarthritis mice (152). Currently, a randomized clinical trial attempting to evaluate teriparatide as a chondroregenerative therapy for OA is ongoing (NCT03072147). This could present a new promising clinical application for the drug by re-purposing it for OA treatment.

Several other hormone receptors were also detected to be expressed in the cartilage tissue or chondrocytes, which may indicate novel targets. For instance, follicle stimulating hormone receptor (FSHR) was detected in mouse chondrocytes and human cartilage tissue (153). Oxytocin receptor (OTR) was expressed in human primary chondrocytes, and significantly reduced in OA chondrocytes (154). Angiotensin II receptor (ATIIR) affected the proliferation and apoptosis of chondrocytes under oxygen-glucose deprivation (155). Activation of melanocortin receptor MCR1 and MCR3 downregulated IL-1 $\beta$, IL- 6 and IL- 8 release, MMPs expression and inhibited cell death in chondrocytes (156). MCR1-deficient mice developed a more severe OA pathology of cartilage degradation (157). Glucagon-like peptide-1 (GLP-1) is an incretin hormone that activates GLP-1R to regulate glucose and energy homeostasis. Exendin-4, a GLP-1R agonist, alleviated chondrocyte apoptosis and ECM degradation in ACL rats (158). Endothelin receptors ETA and ETB were also expressed in rat chondrocytes (159).

\section{OTHER GPCRs IN OA}

There are also some other GPCRs involved in OA which may represent potential targets and will be briefly summarized in this paragraph. The calcium-sensing receptor (CaSR), senses changes in serum $\mathrm{Ca}^{2+}$ in parathyroid glands to regulate PTH. It has been established that knocking out CaSR in chondrocyte prevented matrix degradation in the cartilage of OA mice (160). Frizzled class receptor 4 (FZD4) was shown to be involved in the pathogenesis of temporomandibular joint osteoarthritis, when mediated by miR-101a-3p (161). It has been shown that activation of Kappa opioid receptor (KOR) by chemical agonist $\mathrm{U}-50,488 \mathrm{H}$ inhibited inflammation in arthritic conditions, and $\mathrm{KOR}^{-/-}$mice exhibited accelerated cartilage degeneration in cartilage and subchondral bone defects compared with WT mice $(162,163)$. Extensive studies have indicated that inflammatory diseases decreased the $\mathrm{pH}$ of the cartilage environment (164-166). Acid sensing plays an essential role for maintaining cell function through acid sensing ion channels or proton-activated GPCR $(167,168)$. The proton-activated GPR4 regulates OA pathogenesis via modulating CXCL12/ CXCR7 signaling, and inhibition of GPR4 with NE52-QQ57 ameliorates OA development in both mouse models and human articular cartilage explants (169).

\section{G PROTEIN-COUPLED RECEPTOR KINASE IN OA}

There are seven $G$ protein-coupled receptor kinase (GRKs) subtypes, relevant to the role in GPCR phosphorylation and desensitization, and also phosphorylation of a number of intracellular signaling proteins. Studies demonstrated that GRK5 regulated cartilage degradation in OA progression via $\mathrm{NF}-\kappa \mathrm{B}$ signaling. Intra-articular injection of amlexanox (a selective GRK5 inhibitor and a candidate for OA treatment) protected mouse cartilage against cartilage degradation and reduced the expression of catabolic factors in DMM-induced OA mice (170). Cartilage-specific GRK2 deletion promoted matrix regeneration and prevented $\mathrm{OA}$ progression. Furthermore, the GRK2-inhibiting antidepressant paroxetine decelerated OA progression in DMM mice (171). As a clinically used antidepressant with known pharmacological profiles and safety record, paroxetine offers a promising therapeutic strategy for OA that can be easily translated from bench side to clinics.

\section{PERSPECTIVES AND CONCLUSIONS}

Evidence from preclinical models of OA and/or clinical trials have highlighted multiple GPCRs as novel therapeutic targets in $\mathrm{OA}$ treatment, and showed promising efficacy in managing $\mathrm{OA}$ pain and structural progression (Table 1). For instance, the prominent role in multiple arthritis has rendered the adenosine receptor as a promising target for therapeutic intervention. Particularly, results of clinical trials with polynucleotides in OA patients have been encouraging. Interestingly, the fate of MSCs towards chondrogenesis and osteogenesis can be significantly mediated by adenosines via ecto- $5^{\prime}$-nucleotidase/ CD73 through activation of $\mathrm{A} 2 \mathrm{AR}$ and $\mathrm{A} 2 \mathrm{BR}$ receptors, differentially and respectively $(172,173)$. With this strategy, MSCs for cartilage and bone repair in damaged parts can be adjusted by regulating the activity of $\mathrm{A} 2 \mathrm{AR} / \mathrm{A} 2 \mathrm{BR}$ at different stages of joint repair. Metabolite-sensing GPCRs could be an interesting target for $\mathrm{OA}$ prevention and treatment, but preclinical animal studies and clinical trials are lacking at this time.

In addition to identifying promising drugs for OA management, a well-integrated drug platform incorporating nanocarriers and tissue engineering could provide additional benefits in the treatment of OA. Nanocarriers with a chondrocyte-specific aptamer have been widely used for 
TABLE 1 | GPCRs relevant to OA.

\begin{tabular}{|c|c|c|c|c|c|}
\hline GPCR & Cellular function & Pathogenic function in $\mathrm{OA}$ & Clinical trials & $\begin{array}{l}\text { Agonists/ } \\
\text { antagonist }\end{array}$ & Refs \\
\hline \multicolumn{6}{|c|}{ Cannabinoid receptors } \\
\hline CB1 & Suppress chondrocyte senescence & Inhibit OA pain & NCT00981357 & ACEA & $(26-46)$ \\
\hline CB2 & Promote chondrocyte proteoglycans & Prevent cartilage degradation & & $\begin{array}{l}\text { A-796260 } \\
\text { JWH133 } \\
\text { PF- } \\
04457845\end{array}$ & \\
\hline \multicolumn{6}{|c|}{ Chemokines and receptors } \\
\hline CXCR4 & Induce chondrocyte hypertrophy & Induce cartilage degradation & & $\begin{array}{l}\text { AMD3100 } \\
\text { TN14003 }\end{array}$ & $(49-59)$ \\
\hline CXCR7 & Enhance macrophage chemotaxis & Aggravate joint destruction & & & \\
\hline CXCR $1 / 2$ & $\begin{array}{l}\text { Increase ECM production } \\
\text { Decrease chondrocyte apoptosis }\end{array}$ & & & & $(60,61)$ \\
\hline CCR2 & $\begin{array}{l}\text { Enhance chondrocyte apoptosis } \\
\text { Macrophage infiltration }\end{array}$ & $\begin{array}{l}\text { Aggravate cartilage degradation } \\
\text { Increase synovitis } \\
\text { Increase OA pain }\end{array}$ & NCT00689273 & $\begin{array}{l}\text { RS-504393 } \\
\text { PF- } \\
04136309\end{array}$ & $(66-71)$ \\
\hline \multicolumn{6}{|c|}{ Metabolite-Sensing GPCRs* } \\
\hline GPR40 & $\begin{array}{l}\text { Reduce chondrocyte inflammatory } \\
\text { Inhibit chondrocyte catabolism }\end{array}$ & $\begin{array}{l}\text { Reduce chondral calcification } \\
\text { Reduce osteophyte formation } \\
\text { Reduce subchondral bone sclerosis }\end{array}$ & & GW9508 & $(77,78)$ \\
\hline GPR120 & Protect ECM production & $\begin{array}{l}\text { Prevent cartilage degradation } \\
\text { Reduce synovitis } \\
\text { Reduce subchondral bone structural } \\
\text { change }\end{array}$ & & $\begin{array}{l}\text { TUG891 } \\
\text { GW9508 }\end{array}$ & $(79,80)$ \\
\hline GPR84 & $\begin{array}{l}\text { Increase ECM production } \\
\text { Inhibit chondrocyte catabolism }\end{array}$ & $\begin{array}{l}\text { Prevent cartilage degradation } \\
\text { Reduce osteophyte formation } \\
\text { Reduce subchondral bone sclerosis }\end{array}$ & & $6-\mathrm{OAU}$ & (81) \\
\hline A2BR & Suppress chondrogenic differentiation & & & & (102) \\
\hline $\mathrm{A} 3 \mathrm{R}$ & Induce inflammatory cells apoptosis & $\begin{array}{l}\text { Prevent cartilage degeneration } \\
\text { Prevent bone destruction }\end{array}$ & & CF101 & $(103,104)$ \\
\hline \multicolumn{6}{|c|}{ Protease-activated receptor } \\
\hline Proctaglandin recon & $\begin{array}{l}\text { Promote chondrocyte apoptosis } \\
\text { Promote chondrocyte senescence } \\
\text { Promote chondrocyte inflammatory } \\
\text { Promote chondrocyte catabolism }\end{array}$ & $\begin{array}{l}\text { Aggravate cartilage damage } \\
\text { Increase subchondral bone remodeling } \\
\text { Increase osteophytes formation } \\
\text { Promote OA pain }\end{array}$ & & AZ3451 & $(108-115)$ \\
\hline \multicolumn{6}{|c|}{ Prostaglandin receptors } \\
\hline EP2 & $\begin{array}{l}\text { Enhance chondrocyte differentiation } \\
\text { Protect chondrocyte apoptosis }\end{array}$ & $\begin{array}{l}\text { Increase cartilage regeneration } \\
\text { Lessen Joint pain } \\
\text { Prevent cartilage degeneration }\end{array}$ & & ONO-8815Ly & $(119-125)$ \\
\hline EP4 & $\begin{array}{l}\text { Chondrocyte catabolism } \\
\text { Inflammation }\end{array}$ & $\begin{array}{l}\text { Matrix degradation } \\
\text { Synovitis } \\
\text { OA pain }\end{array}$ & & $\begin{array}{l}\text { AH23848 } \\
\text { Grapiprant }\end{array}$ & $(126-133)$ \\
\hline \multicolumn{6}{|c|}{ Hormone receptors } \\
\hline $\begin{array}{l}\alpha 2 \mathrm{~A} \text {-adreno- } \\
\text { receptor }\end{array}$ & $\begin{array}{l}\text { Decrease chondrocyte metabolism } \\
\text { Inhibit chondrocyte inflammatory }\end{array}$ & $\begin{array}{l}\text { Prevent cartilage degeneration } \\
\text { Prevent subchondral bone loss }\end{array}$ & & & $(135,136)$ \\
\hline$\beta$-adreno-receptor & $\begin{array}{l}\text { Protect chondrocyte proliferation } \\
\text { Inhibit chondrocyte catabolism } \\
\text { Protect ECM production }\end{array}$ & & & & $(137)$ \\
\hline PTH/PTHrP receptor & Slow chondrocyte proliferation & Decelerate cartilage degeneration & NCT03072147 & teriparatide & $(149-152)$ \\
\hline
\end{tabular}


TABLE 1 | Continued

\begin{tabular}{|c|c|c|c|c|c|}
\hline GPCR & Cellular function & Pathogenic function in OA & Clinical trials & $\begin{array}{l}\text { Agonists/ } \\
\text { antagonist }\end{array}$ & Refs \\
\hline & Delay chondrocyte hypertrophy & Induce matrix regeneration & & & \\
\hline ATIIR & Affect chondrocyte proliferation and apoptosis & & & & (155) \\
\hline MCR1 & Inhibit chondrocyte catabolism & $\begin{array}{l}\text { Prevent cartilage degradation } \\
\text { Prevent bone remodeling }\end{array}$ & & & $(156,157)$ \\
\hline GLP-1R & Alleviate chondrocyte apoptosis & Decelerate ECM degradation & & Exendin-4 & $(158)$ \\
\hline \multicolumn{6}{|c|}{ Other GPCRs in OA } \\
\hline CaSR & $\begin{array}{l}\text { Inhibit chondrocyte differentiation } \\
\text { Inhibit ECM production }\end{array}$ & Aggravate cartilage degradation & & & $(160)$ \\
\hline KOR & $\begin{array}{l}\text { Increase lubricin production } \\
\text { Increase GAG synthesis }\end{array}$ & $\begin{array}{l}\text { Prevent cartilage degeneration } \\
\text { Prevent subchondral bone defect } \\
\text { Prevent joint inflammation }\end{array}$ & & $\mathrm{U}-50,488 \mathrm{H}$ & $(162,163)$ \\
\hline GPR4 & $\begin{array}{l}\text { Inhibit ECM production } \\
\text { Upregulate Chondrocyte inflammatory and } \\
\text { catabolism }\end{array}$ & $\begin{array}{l}\text { Aggravate cartilage damage } \\
\text { Increase synovitis } \\
\text { Increase osteophytes formation }\end{array}$ & & NE52-QQ57 & $(169)$ \\
\hline
\end{tabular}

${ }^{*}$ Promising target for OA treatment and prevention.

sustained delivery in cartilage tissue, providing improved targeting specificity and pharmacokinetic profile (174-176). Tissue engineering can lead to the construction of a 'native' microenvironment to deliver drug/growth factors, maintain ECM deposition and support mechanical properties as naïve cartilage $(177,178)$. This integration may form new approaches to the prevention and treatment of OA.

On paper, many of the pathways can be selectively and potently targeted, offering exciting opportunities for OA management. However, it should be noted that complex pathogenic mechanisms of OA limit clinical applications for OA patients. Thus, future research should be directed towards elucidating how these different pathways interact to that drive structural progression or OA pain. Moreover, heterogeneity in clinical presentation and histopathology can make it difficult to elucidate OA pathophysiological changes. In a study published last year, OA patients were classified into four distinct osteoarthritis subtypes with a knee joint tissue transcriptome atlas: a glycosaminoglycan metabolic disorder subtype (C1), a collagen metabolic disorder subtype (C2), an activated sensory neuron subtype (C3), and an inflammation subtype (C4) (179). This provides a new paradigm for precision medicine in the diagnosis and treatment of $\mathrm{OA}$, although they may contradict traditional $\mathrm{OA}$ diagnosis by clinical and radiographic presentation. Hence, research that defines meaningful OA

\section{REFERENCES}

1. Litwic A, Edwards MH, Dennison EM, Cooper C. Epidemiology and Burden of Osteoarthritis. Br Med Bull (2013) 105:185-99. doi: 10.1093/bmb/lds038

2. Hunter DJ, Schofield D, Callander E. The Individual and Socioeconomic Impact of Osteoarthritis. Nat Rev Rheumatol (2014) 10:437-41. doi: 10.1038/nrrheum.2014.44

3. Tchetina EV. Developmental Mechanisms in Articular Cartilage Degradation in Osteoarthritis. Arthritis (2011) 2011:683970. doi: 10.1155/ 2011/683970

4. Zhang W, Ouyang H, Dass CR, Xu J. Current Research on Pharmacologic and Regenerative Therapies for Osteoarthritis. Bone Res (2016) 4:15040. doi: 10.1038/boneres.2015.40 phenotypes will be critical in determining optimal treatment strategy, and should be prioritized.

In this review, we have described the pathophysiological processes targeted by GPCRs in OA, along with related preclinical models and/or clinical trials data, and discussed the main challenges and developments for these potential therapies. Further studies are warranted to confirm the translatable symptomatic and long-term benefits of candidate drugs. Meanwhile, expanding the knowledge of the pathophysiological roles of agonists, antagonists or autoantibodies for GPCRs will shed light on the biology of these receptors and provide new insights for potential therapeutic approaches.

\section{AUTHOR CONTRIBUTIONS}

FW wrote the article. All authors made a substantial contribution to discussion of content and reviewed or edited the manuscript before submission.

\section{FUNDING}

This work was supported by grants from the Fundamental Research Funds for the Central Universities (22120210586 to JL), Ministry of Science and Technology of China (2020YFC2002800 to JL), the National Natural Science Foundation of China (91949127 to JL).

5. Goldring SR, Goldring MB. Changes in the Osteochondral Unit During Osteoarthritis: Structure, Function and Cartilage-Bone Crosstalk. Nat Rev Rheumatol (2016) 12:632-44. doi: 10.1038/nrrheum.2016.148

6. Martel-Pelletier J, Barr AJ, Cicuttini FM, Conaghan PG, Cooper C, Goldring MB, et al. Osteoarthritis. Nat Rev Dis Primers (2016) 2:16072. doi: 10.1038/ nrdp. 2016.72

7. Hu W, Chen Y, Dou C, Dong S. Microenvironment in Subchondral Bone: Predominant Regulator for the Treatment of Osteoarthritis. Ann Rheum Dis (2020) 80:413-22. doi: 10.1136/annrheumdis-2020-218089

8. Leopoldino AO, Machado GC, Ferreira PH, Pinheiro MB, Day R, McLachlan AJ, et al. Paracetamol Versus Placebo for Knee and Hip Osteoarthritis. Cochrane Database Syst Rev (2019) 2:CD013273. doi: 10.1002/14651858.CD013273 
9. Bannuru RR, Schmid CH, Kent DM, Vaysbrot EE, Wong JB, McAlindon TE. Comparative Effectiveness of Pharmacologic Interventions for Knee Osteoarthritis: A Systematic Review and Network Meta-Analysis. Ann Intern Med (2015) 162:46-54. doi: 10.7326/M14-1231

10. Juni P, Hari R, Rutjes AW, Fischer R, Silletta MG, Reichenbach S, et al. IntraArticular Corticosteroid for Knee Osteoarthritis. Cochrane Database Syst Rev (2015) 10:CD005328. doi: 10.1002/14651858.CD005328.pub3

11. Zhang W, Robertson WB, Zhao J, Chen W, Xu J. Emerging Trend in the Pharmacotherapy of Osteoarthritis. Front Endocrinol (Lausanne) (2019) 10:431. doi: 10.3389/fendo.2019.00431

12. Foord SM, Bonner TI, Neubig RR, Rosser EM, Pin JP, Davenport AP, et al. International Union of Pharmacology. XLVI. G Protein-Coupled Receptor List. Pharmacol Rev (2005) 57:279-88. doi: 10.1124/pr.57.2.5

13. Lagerstrom MC, Schioth HB. Structural Diversity of G Protein-Coupled Receptors and Significance for Drug Discov. Nat Rev Drug Discov (2008) 7:339-57. doi: $10.1038 / \mathrm{nrd} 2518$

14. Hauser AS, Attwood MM, Rask-Andersen M, Schioth HB, Gloriam DE. Trends in GPCR Drug Discovery: New Agents, Targets and Indications. Nat Rev Drug Discov (2017) 16:829-42. doi: 10.1038/nrd.2017.178

15. Khan SM, Sleno R, Gora S, Zylbergold P, Laverdure JP, Labbe JC, et al. The Expanding Roles of Gbetagamma Subunits in G Protein-Coupled Receptor Signaling and Drug Action. Pharmacol Rev (2013) 65:545-77. doi: 10.1124/ pr.111.005603

16. Oldham WM, Hamm HE. Structural Basis of Function in Heterotrimeric G Proteins. Q Rev Biophys (2006) 39:117-66. doi: 10.1017/S0033583506004306

17. Calebiro D, Koszegi Z, Lanoiselee Y, Miljus T, O'Brien S. G Protein-Coupled Receptor-G Protein Interactions: A Single-Molecule Perspective. Physiol Rev (2021) 101:857-906. doi: 10.1152/physrev.00021.2020

18. Smrcka AV. G Protein Betagamma Subunits: Central Mediators of G Protein-Coupled Receptor Signaling. Cell Mol Life Sci (2008) 65:2191-214. doi: 10.1007/s00018-008-8006-5

19. Weis WI, Kobilka BK. The Molecular Basis of G Protein-Coupled Receptor Activation. Annu Rev Biochem (2018) 87:897-919. doi: 10.1146/annurevbiochem-060614-033910

20. Suomivuori CM, Latorraca NR, Wingler LM, Eismann S, King MC, Kleinhenz ALW, et al. Molecular Mechanism of Biased Signaling in a Prototypical G Protein-Coupled Receptor. Science (2020) 367:881-7. doi: $10.1126 /$ science.aaz0326

21. Ghislain J, Poitout V. Targeting Lipid GPCRs to Treat Type 2 Diabetes Mellitus - Progress and Challenges. Nat Rev Endocrinol (2021) 17:162-75. doi: 10.1038/s41574-020-00459-w

22. Davenport AP, Scully CCG, de Graaf C, Brown AJH, Maguire JJ. Advances in Therapeutic Peptides Targeting G Protein-Coupled Receptors. Nat Rev Drug Discov (2020) 19:389-413. doi: 10.1038/s41573-020-0062-z

23. Tan JK, McKenzie C, Marino E, Macia L, Mackay CR. Metabolite-Sensing G Protein-Coupled Receptors-Facilitators of Diet-Related Immune Regulation. Annu Rev Immunol (2017) 35:371-402. doi: 10.1146/annurev-immunol051116-052235

24. Donvito G, Nass SR, Wilkerson JL, Curry ZA, Schurman LD, Kinsey SG, et al. The Endogenous Cannabinoid System: A Budding Source of Targets for Treating Inflammatory and Neuropathic Pain. Neuropsychopharmacology (2018) 43:52-79. doi: 10.1038/npp.2017.204

25. Munro S, Thomas KL, Abu-Shaar M. Molecular Characterization of a Peripheral Receptor for Cannabinoids. Nature (1993) 365:61-5. doi: $10.1038 / 365061 \mathrm{a} 0$

26. Dunn SL, Wilkinson JM, Crawford A, Le Maitre CL, Bunning RA. Cannabinoid WIN-55,212-2 Mesylate Inhibits Interleukin-1beta Induced Matrix Metalloproteinase and Tissue Inhibitor of Matrix Metalloproteinase Expression in Human Chondrocytes. Osteoarthritis Cartilage (2014) 22:13344. doi: 10.1016/j.joca.2013.10.016

27. Rossi F, Siniscalco D, Luongo L, De Petrocellis L, Bellini G, Petrosino S, et al. The Endovanilloid/Endocannabinoid System in Human Osteoclasts: Possible Involvement in Bone Formation and Resorption. Bone (2009) 44:476-84. doi: 10.1016/j.bone.2008.10.056

28. Richardson D, Pearson RG, Kurian N, Latif ML, Garle MJ, Barrett DA, et al. Characterisation of the Cannabinoid Receptor System in Synovial Tissue and Fluid in Patients With Osteoarthritis and Rheumatoid Arthritis. Arthritis Res Ther (2008) 10:R43. doi: 10.1186/ar2401
29. Dunn SL, Wilkinson JM, Crawford A, Le Maitre CL, Bunning RA. Cannabinoids: Novel Therapies for Arthritis? Future Med Chem (2012) 4:713-25. doi: $10.4155 /$ fmc. 12.20

30. Mbvundula EC, Bunning RA, Rainsford KD. Effects of Cannabinoids on Nitric Oxide Production by Chondrocytes and Proteoglycan Degradation in Cartilage. Biochem Pharmacol (2005) 69:635-40. doi: 10.1016/j.bcp.2004.11.018

31. Zhang D, Zhang G, Li Z, Li B. Activation of the Cannabinoid Receptor 1 by ACEA Suppresses Senescence in Human Primary Chondrocytes Through Sirt1 Activation. Exp Biol Med (Maywood) (2018) 243:437-43. doi: 10.1177/ 1535370218757950

32. Sophocleous A, Borjesson AE, Salter DM, Ralston SH. The Type 2 Cannabinoid Receptor Regulates Susceptibility to Osteoarthritis in Mice. Osteoarthritis Cartilage (2015) 23:1586-94. doi: 10.1016/j.joca.2015.04.020

33. Idris AI, Ralston SH. Role of Cannabinoids in the Regulation of Bone Remodeling. Front Endocrinol (Lausanne) (2012) 3:136. doi: 10.3389/ fendo.2012.00136

34. Ofek O, Karsak M, Leclerc N, Fogel M, Frenkel B, Wright K, et al. Peripheral Cannabinoid Receptor, CB2, Regulates Bone Mass. Proc Natl Acad Sci USA (2006) 103:696-701. doi: 10.1073/pnas.0504187103

35. Lian JB, Javed A, Zaidi SK, Lengner C, Montecino M, van Wijnen AJ, et al. Regulatory Controls for Osteoblast Growth and Differentiation: Role of Runx/Cbfa/AML Factors. Crit Rev Eukaryot Gene Expr (2004) 14:1-41. doi: 10.1615/CritRevEukaryotGeneExpr.v14.i12.10

36. Apostu D, Lucaciu O, Mester A, Benea H, Oltean-Dan D, Onisor F, et al. Cannabinoids and Bone Regeneration. Drug Metab Rev (2019) 51:65-75. doi: 10.1080/03602532.2019.1574303

37. Meah F, Lundholm M, Emanuele N, Amjed H, Poku C, Agrawal L, et al. The Effects of Cannabis and Cannabinoids on the Endocrine System. Rev Endocr Metab Disord (2021) 8:1-20. doi: 10.1007/s11154-021-09682-w

38. Schuelert N, McDougall JJ. Grading of Monosodium Iodoacetate-Induced Osteoarthritis Reveals a Concentration-Dependent Sensitization of Nociceptors in the Knee Joint of the Rat. Neurosci Lett (2009) 465:184-8. doi: 10.1016/j.neulet.2009.08.063

39. Valverde O, Karsak M, Zimmer A. Analysis of the Endocannabinoid System by Using CB1 Cannabinoid Receptor Knockout Mice. Handb Exp Pharmacol (2005) 168:117-45. doi: 10.1007/3-540-26573-2_4

40. Schuelert N, Zhang C, Mogg AJ, Broad LM, Hepburn DL, Nisenbaum ES, et al. Paradoxical Effects of the Cannabinoid CB2 Receptor Agonist GW405833 on Rat Osteoarthritic Knee Joint Pain. Osteoarthritis Cartilage (2010) 18:1536-43. doi: 10.1016/j.joca.2010.09.005

41. Marker CL, Pomonis JD. The Monosodium Iodoacetate Model of Osteoarthritis Pain in the Rat. Methods Mol Biol (2012) 851:239-48. doi: 10.1007/978-1-61779-561-9_18

42. Wang J, Wei W, Zhang X, Cao S, Hu B, Ye Y, et al. Synthesis and Biological Evaluation of C-17-Amino-Substituted Pyrazole-Fused Betulinic Acid Derivatives as Novel Agents for Osteoarthritis Treatment. J Med Chem (2021) 64:13676-92. doi: 10.1021/acs.jmedchem.1c01019

43. Mlost J, Kostrzewa M, Borczyk M, Bryk M, Chwastek J, Korostynski M, et al. CB2 Agonism Controls Pain and Subchondral Bone Degeneration Induced by Mono-Iodoacetate: Implications GPCR Functional Bias and Tolerance Development. BioMed Pharmacother (2021) 136:111283. doi: 10.1016/ j.biopha.2021.111283

44. Schuelert N, McDougall JJ. Cannabinoid-Mediated Antinociception is Enhanced in Rat Osteoarthritic Knees. Arthritis Rheumatol (2008) 58:14553. doi: $10.1002 /$ art.23156

45. Yao BB, Hsieh GC, Frost JM, Fan Y, Garrison TR, Daza AV, et al. In Vitro and In Vivo Characterization of A-796260: A Selective Cannabinoid CB2 Receptor Agonist Exhibiting Analgesic Activity in Rodent Pain Models. $\mathrm{Br} J$ Pharmacol (2008) 153:390-401. doi: 10.1038/sj.bjp.0707568

46. Huggins JP, Smart TS, Langman S, Taylor L, Young T. An Efficient Randomised, Placebo-Controlled Clinical Trial With the Irreversible Fatty Acid Amide Hydrolase-1 Inhibitor PF-04457845, Which Modulates Endocannabinoids But Fails to Induce Effective Analgesia in Patients With Pain Due to Osteoarthritis of the Knee. Pain (2012) 153:1837-46. doi: 10.1016/j.pain.2012.04.020

47. Miyabe Y, Lian J, Miyabe C, Luster AD. Chemokines in Rheumatic Diseases: Pathogenic Role and Therapeutic Implications. Nat Rev Rheumatol (2019) 15:731-46. doi: 10.1038/s41584-019-0323-6 
48. Griffith JW, Sokol CL, Luster AD. Chemokines and Chemokine Receptors: Positioning Cells for Host Defense and Immunity. Annu Rev Immunol (2014) 32:659-702. doi: 10.1146/annurev-immunol-032713-120145

49. Li J, Chen H, Zhang D, Xie J, Zhou X. The Role of Stromal Cell-Derived Factor 1 on Cartilage Development and Disease. Osteoarthritis Cartilage (2021) 29:313-22. doi: 10.1016/j.joca.2020.10.010

50. Janssens R, Struyf S, Proost P. Pathological Roles of the Homeostatic Chemokine CXCL12. Cytokine Growth Factor Rev (2018) 44:51-68. doi: 10.1016/j.cytogfr.2018.10.004

51. Gao H, Priebe W, Glod J, Banerjee D. Activation of Signal Transducers and Activators of Transcription 3 and Focal Adhesion Kinase by Stromal CellDerived Factor 1 Is Required for Migration of Human Mesenchymal Stem Cells in Response to Tumor Cell-Conditioned Medium. Stem Cells (2009) 27:857-65. doi: 10.1002/stem.23

52. Wei L, Kanbe K, Lee M, Wei X, Pei M, Sun X, et al. Stimulation of Chondrocyte Hypertrophy by Chemokine Stromal Cell-Derived Factor 1 in the Chondro-Osseous Junction During Endochondral Bone Formation. Dev Biol (2010) 341:236-45. doi: 10.1016/j.ydbio.2010.02.033

53. Lu W, Shi J, Zhang J, Lv Z, Guo F, Huang H, et al. CXCL12/CXCR4 Axis Regulates Aggrecanase Activation and Cartilage Degradation in a PostTraumatic Osteoarthritis Rat Model. Int J Mol Sci (2016) 17:1522. doi: 10.3390/ijms17101522

54. Qin HJ, Xu T, Wu HT, Yao ZL, Hou YL, Xie YH, et al. SDF-1/CXCR4 Axis Coordinates Crosstalk Between Subchondral Bone and Articular Cartilage in Osteoarthritis Pathogenesis. Bone (2019) 125:140-50. doi: 10.1016/ j.bone.2019.05.010

55. Goumans MJ, Valdimarsdottir G, Itoh S, Lebrin F, Larsson J, Mummery C, et al. Activin Receptor-Like Kinase (ALK)1 Is an Antagonistic Mediator of Lateral TGFbeta/ALK5 Signaling. Mol Cell (2003) 12:817-28. doi: 10.1016/ s1097-2765(03)00386-1

56. Finnson KW, Parker WL, ten Dijke P, Thorikay M, Philip A. ALK1 Opposes ALK5/Smad3 Signaling and Expression of Extracellular Matrix Components in Human Chondrocytes. J Bone Miner Res (2008) 23:896-906. doi: 10.1359/ jbmr.080209

57. Jia D, Li Y, Han R, Wang K, Cai G, He C, et al. Mir146a5p Expression is Upregulated by the CXCR4 Antagonist TN14003 and Attenuates SDFlinduced Cartilage Degradation. Mol Med Rep (2019) 19:4388-400. doi: $10.3892 / \mathrm{mmr} .2019 .10076$

58. Yu T, Wu Y, Helman JI, Wen Y, Wang C, Li L. CXCR4 Promotes Oral Squamous Cell Carcinoma Migration and Invasion Through Inducing Expression of MMP-9 and MMP-13 via the ERK Signaling Pathway. Mol Cancer Res (2011) 9:161-72. doi: 10.1158/1541-7786.MCR-10-0386

59. Kuang L, Wu J, Su N, Qi H, Chen H, Zhou S, et al. FGFR3 Deficiency Enhances CXCL12-Dependent Chemotaxis of Macrophages via Upregulating CXCR7 and Aggravates Joint Destruction in Mice. Ann Rheum Dis (2020) 79:112-22. doi: 10.1136/annrheumdis-2019-215696

60. Sherwood J, Bertrand J, Nalesso G, Poulet B, Pitsillides A, Brandolini L, et al. A Homeostatic Function of CXCR2 Signalling in Articular Cartilage. Ann Rheum Dis (2015) 74:2207-15. doi: 10.1136/annrheumdis-2014-205546

61. Onuora S. Osteoarthritis: A Role for CXCR2 Signalling in Cartilage Homeostasis. Nat Rev Rheumatol (2014) 10:576. doi: 10.1038/nrrheum.2014.148

62. Yin ZC, Xiong WH, Pang QJ. CXCR3 Mediates Chondrocyte Injury Through Regulating Nitric Oxide. Eur Rev Med Pharmacol Sci (2018) 22:2454-60. doi: 10.26355/eurrev_201804_14839

63. Benigni G, Dimitrova P, Antonangeli F, Sanseviero E, Milanova V, Blom A, et al. CXCR3/CXCL10 Axis Regulates Neutrophil-NK Cell Cross-Talk Determining the Severity of Experimental Osteoarthritis. I Immunol (2017) 198:2115-24. doi: 10.4049/jimmunol.1601359

64. Takebe K, Rai MF, Schmidt EJ, Sandell LJ. The Chemokine Receptor CCR5 Plays a Role in Post-Traumatic Cartilage Loss in Mice, But Does Not Affect Synovium and Bone. Osteoarthritis Cartilage (2015) 23:454-61. doi: 10.1016/ j.joca.2014.12.002

65. Zhu S, Liu M, Bennett S, Wang Z, Pfleger KDG, Xu J. The Molecular Structure and Role of CCL2 (MCP-1) and C-C Chemokine Receptor CCR2 in Skeletal Biology and Diseases. J Cell Physiol (2021) 236:7211-22. doi: 10.1002/jcp.30375

66. Xu YK, Ke Y, Wang B, Lin JH. The Role of MCP-1-CCR2 Ligand-Receptor Axis in Chondrocyte Degradation and Disease Progress in Knee Osteoarthritis. Biol Res (2015) 48:64. doi: 10.1186/s40659-015-0057-0
67. Raghu H, Lepus CM, Wang Q, Wong HH, Lingampalli N, Oliviero F, et al. CCL2/CCR2, But Not CCL5/CCR5, Mediates Monocyte Recruitment, Inflammation and Cartilage Destruction in Osteoarthritis. Ann Rheum Dis (2017) 76:914-22. doi: 10.1136/annrheumdis-2016-210426

68. Atzeni F, Cazzola M, Benucci M, Di Franco M, Salaffi F, Sarzi-Puttini P. Chronic Widespread Pain in the Spectrum of Rheumatological Diseases. Best Pract Res Clin Rheumatol (2011) 25:165-71. doi: 10.1016/j.berh.2010.01.011

69. Ishihara S, Obeidat AM, Wokosin DL, Ren D, Miller RJ, Malfait AM, et al. The Role of Intra-Articular Neuronal CCR2 Receptors in Knee Joint Pain Associated With Experimental Osteoarthritis in Mice. Arthritis Res Ther (2021) 23:103. doi: 10.1186/s13075-021-02486-y

70. Miotla Zarebska J, Chanalaris A, Driscoll C, Burleigh A, Miller RE, Malfait AM, et al. CCL2 and CCR2 Regulate Pain-Related Behaviour and Early Gene Expression in Post-Traumatic Murine Osteoarthritis But Contribute Little to Chondropathy. Osteoarthritis Cartilage (2017) 25:406-12. doi: 10.1016/ j.joca.2016.10.008

71. Miller RE, Tran PB, Das R, Ghoreishi-Haack N, Ren D, Miller RJ, et al. CCR2 Chemokine Receptor Signaling Mediates Pain in Experimental Osteoarthritis. Proc Natl Acad Sci USA (2012) 109:20602-7. doi: 10.1073/ pnas. 1209294110

72. Loef M, Schoones JW, Kloppenburg M, Ioan-Facsinay A. Fatty Acids and Osteoarthritis: Different Types, Different Effects. Joint Bone Spine (2019) 86:451-8. doi: 10.1016/j.jbspin.2018.07.005

73. Wu CL, Jain D, McNeill JN, Little D, Anderson JA, Huebner JL, et al. Dietary Fatty Acid Content Regulates Wound Repair and the Pathogenesis of Osteoarthritis Following Joint Injury. Ann Rheum Dis (2015) 74:2076-83. doi: 10.1136/annrheumdis-2014-205601

74. Koren N, Simsa-Maziel S, Shahar R, Schwartz B, Monsonego-Ornan E. Exposure to Omega-3 Fatty Acids at Early Age Accelerate Bone Growth and Improve Bone Quality. J Nutr Biochem (2014) 25:623-33. doi: 10.1016/ j.jnutbio.2014.01.012

75. Montalvany-Antonucci CC, Duffles LF, de Arruda JAA, Zicker MC, de Oliveira S, Macari S, et al. Short-Chain Fatty Acids and FFAR2 as Suppressors of Bone Resorption. Bone (2019) 125:112-21. doi: 10.1016/ j.bone.2019.05.016

76. Lucas S, Omata Y, Hofmann J, Bottcher M, Iljazovic A, Sarter K, et al. ShortChain Fatty Acids Regulate Systemic Bone Mass and Protect From Pathological Bone Loss. Nat Commun (2018) 9:55. doi: 10.1038/s41467017-02490-4

77. Monfoulet LE, Philippe C, Mercier S, Coxam V, Wittrant Y. Deficiency of GProtein Coupled Receptor 40, a Lipid-Activated Receptor, Heightens In Vitro- and In Vivo-Induced Murine Osteoarthritis. Exp Biol Med (Maywood) (2015) 240:854-66. doi: 10.1177/1535370214565078

78. Gu J, Lin H, Zhang Y, Xu T, Wang T, Xue X, et al. Activation of GPR40 Suppresses AGE-Induced Reduction of Type II Collagen and Aggrecan in Human SW1353 Chondrocytes. Drug Des Devel Ther (2020) 14:2371-9. doi: 10.2147/DDDT.S239273

79. Chen Y, Zhang D, Ho KW, Lin S, Suen WC, Zhang H, et al. GPR120 is an Important Inflammatory Regulator in the Development of Osteoarthritis. Arthritis Res Ther (2018) 20:163. doi: 10.1186/s13075-018-1660-6

80. Xu Z, Ke T, Zhang Y, Fu C, He W. Agonism of GPR120 Prevented IL-1betaInduced Reduction of Extracellular Matrix Through SOX-9. Aging (Albany NY) (2020) 12:12074-85. doi: 10.18632/aging.103375

81. Wang F, Ma L, Ding Y, He L, Chang M, Shan Y, et al. Fatty Acid Sensing GPCR (GPR84) Signaling Safeguards Cartilage Homeostasis and Protects Against Osteoarthritis. Pharmacol Res (2021) 164:105406. doi: 10.1016/ j.phrs.2020.105406

82. Pirozzi C, Francisco V, Guida FD, Gomez R, Lago F, Pino J, et al. Butyrate Modulates Inflammation in Chondrocytes via GPR43 Receptor. Cell Physiol Biochem (2018) 51:228-43. doi: 10.1159/000495203

83. Zhuo W, Li B, Zhang D. Activation of G-Protein-Coupled Bile Acid Receptor Gpbar1 (TGR5) Inhibits Degradation of Type II Collagen and Aggrecan in Human Chondrocytes. Eur J Pharmacol (2019) 856:172387. doi: 10.1016/j.ejphar.2019.05.016

84. Huang H, Lei H, Yang F, Fan X, Dang Q, Li Y. Activation of the Bile Acid Receptor GPBAR1 (TGR5) Ameliorates Interleukin-1beta (IL-1beta)Induced Chondrocytes Senescence. BioMed Pharmacother (2018) 106:1713-9. doi: 10.1016/j.biopha.2018.06.154 
85. Jacobson KA, Gao ZG. Adenosine Receptors as Therapeutic Targets. Nat Rev Drug Discov (2006) 5:247-64. doi: 10.1038/nrd1983

86. Hasko G, Linden J, Cronstein B, Pacher P. Adenosine Receptors: Therapeutic Aspects for Inflammatory and Immune Diseases. Nat Rev Drug Discov (2008) 7:759-70. doi: 10.1038/nrd2638

87. Hoebertz A, Arnett TR, Burnstock G. Regulation of Bone Resorption and Formation by Purines and Pyrimidines. Trends Pharmacol Sci (2003) 24:290-7. doi: 10.1016/S0165-6147(03)00123-8

88. Lopez CD, Bekisz JM, Corciulo C, Mediero A, Coelho PG, Witek L, et al. Local Delivery of Adenosine Receptor Agonists to Promote Bone Regeneration and Defect Healing. Adv Drug Deliv Rev (2019) 146:240-7. doi: 10.1016/j.addr.2018.06.010

89. Koolpe M, Pearson D, Benton HP. Expression of Both P1 and P2 Purine Receptor Genes by Human Articular Chondrocytes and Profile of LigandMediated Prostaglandin E2 Release. Arthritis Rheumatol (1999) 42:258-67. doi: 10.1002/1529-0131(199902)42:2<258::AID-ANR7>3.0.CO;2-O

90. Tesch AM, MacDonald MH, Kollias-Baker C, Benton HP. Endogenously Produced Adenosine Regulates Articular Cartilage Matrix Homeostasis: Enzymatic Depletion of Adenosine Stimulates Matrix Degradation. Osteoarthritis Cartilage (2004) 12:349-59. doi: 10.1016/j.joca.2004.01.002

91. Loeser RF, Collins JA, Diekman BO. Ageing and the Pathogenesis of Osteoarthritis. Nat Rev Rheumatol (2016) 12:412-20. doi: 10.1038/ nrrheum. 2016.65

92. Corciulo C, Lendhey M, Wilder T, Schoen H, Cornelissen AS, Chang G, et al. Endogenous Adenosine Maintains Cartilage Homeostasis and Exogenous Adenosine Inhibits Osteoarthritis Progression. Nat Commun (2017) 8:15019. doi: 10.1038/ncomms15019

93. Campo GM, Avenoso A, D’Ascola A, Prestipino V, Scuruchi M, Nastasi G, et al. The Stimulation of Adenosine 2A Receptor Reduces Inflammatory Response in Mouse Articular Chondrocytes Treated With Hyaluronan Oligosaccharides. Matrix Biol (2012) 31:338-51. doi: 10.1016/ j.matbio.2012.07.001

94. Li QH, Xie WX, Li XP, Huang KT, Du ZH, Cong WJ, et al. Adenosine A2A Receptors Mediate Anti-Inflammatory Effects of Electroacupuncture on Synovitis in Mice With Collagen-Induced Arthritis. Evid Based Complement Alternat Med (2015) 2015:809560. doi: 10.1155/2015/809560

95. Castro CM, Corciulo C, Solesio ME, Liang F, Pavlov EV, Cronstein BN. Adenosine A2A Receptor (A2AR) Stimulation Enhances Mitochondrial Metabolism and Mitigates Reactive Oxygen Species-Mediated Mitochondrial Injury. FASEB J (2020) 34:5027-45. doi: 10.1096/ fj.201902459R

96. Gennero L, Denysenko T, Calisti GF, Vercelli A, Vercelli CM, Amedeo S, et al. Protective Effects of Polydeoxyribonucleotides on Cartilage Degradation in Experimental Cultures. Cell Biochem Funct (2013) 31:21427. doi: $10.1002 / \mathrm{cbf} .2875$

97. Bitto A, Polito F, Irrera N, D'Ascola A, Avenoso A, Nastasi G, et al. Polydeoxyribonucleotide Reduces Cytokine Production and the Severity of Collagen-Induced Arthritis by Stimulation of Adenosine A((2)A) Receptor. Arthritis Rheumatol (2011) 63:3364-71. doi: 10.1002/art.30538

98. Vanelli R, Costa P, Rossi SM, Benazzo F. Efficacy of Intra-Articular Polynucleotides in the Treatment of Knee Osteoarthritis: A Randomized, Double-Blind Clinical Trial. Knee Surg Sports Traumatol Arthrosc (2010) 18:901-7. doi: 10.1007/s00167-009-1039-y

99. Giarratana LS, Marelli BM, Crapanzano C, De Martinis SE, Gala L, Ferraro M, et al. A Randomized Double-Blind Clinical Trial on the Treatment of Knee Osteoarthritis: The Efficacy of Polynucleotides Compared to Standard Hyaluronian Viscosupplementation. Knee (2014) 21:661-8. doi: 10.1016/ j.knee.2014.02.010

100. Dallari D, Sabbioni G, Del Piccolo N, Carubbi C, Veronesi F, Torricelli P, et al. Efficacy of Intra-Articular Polynucleotides Associated With Hyaluronic Acid Versus Hyaluronic Acid Alone in the Treatment of Knee Osteoarthritis: A Randomized, Double-Blind, Controlled Clinical Trial. Clin J Sport Med (2020) 30:1-7. doi: 10.1097/JSM.0000000000000569

101. Stagni C, Rocchi M, Mazzotta A, Del Piccolo N, Rani N, Govoni M, et al. Randomised, Double-Blind Comparison of a Fixed Co-Formulation of IntraArticular Polynucleotides and Hyaluronic Acid Versus Hyaluronic Acid Alone in the Treatment of Knee Osteoarthritis: Two-Year Follow-Up. BMC Musculoskelet Disord (2021) 22:773. doi: 10.1186/s12891-021-04648-0
102. Tan L, Zhao B, Ge FT, Sun DH, Yu T. Shockwaves Inhibit Chondrogenic Differentiation of Human Mesenchymal Stem Cells in Association With Adenosine and A2B Receptors. Sci Rep (2017) 7:14377. doi: 10.1038/s41598017-14875-y

103. Shkhyan R, Lee S, Gullo F, Li L, Peleli M, Carlstrom M, et al. Genetic Ablation of Adenosine Receptor A3 Results in Articular Cartilage Degeneration. J Mol Med (Berl) (2018) 96:1049-60. doi: 10.1007/s00109-018-1680-3

104. Bar-Yehuda S, Rath-Wolfson L, Del Valle L, Ochaion A, Cohen S, Patoka R, et al. Induction of an Antiinflammatory Effect and Prevention of Cartilage Damage in Rat Knee Osteoarthritis by CF101 Treatment. Arthritis Rheumatol (2009) 60:3061-71. doi: 10.1002/art.24817

105. Cederbaum SD, Kaitila I, Rimoin DL, Stiehm ER. The Chondro-Osseous Dysplasia of Adenosine Deaminase Deficiency With Severe Combined Immunodeficiency. J Pediatr (1976) 89:737-42. doi: 10.1016/s0022-3476 (76)80793-7

106. Hirschhorn R, Roegner V, Rubinstein A, Papageorgiou P. Plasma Deoxyadenosine, Adenosine, and Erythrocyte deoxyATP are Elevated at Birth in an Adenosine Deaminase-Deficient Child. J Clin Invest (1980) 65:768-71. doi: 10.1172/JCI109725

107. Oikonomopoulou K, Diamandis EP, Hollenberg MD, Chandran V. Proteinases and Their Receptors in Inflammatory Arthritis: An Overview. Nat Rev Rheumatol (2018) 14:170-80. doi: 10.1038/nrrheum.2018.17

108. Abramson FP. Two-Compartment Pharmacokinetic Models: Computer Simulations of Their Characteristics and Clinical Consequences. J Pharm Sci (1981) 70:141-6. doi: 10.1002/jps.2600700207

109. Xiang Y, Masuko-Hongo K, Sekine T, Nakamura H, Yudoh K, Nishioka K, et al. Expression of Proteinase-Activated Receptors (PAR)-2 in Articular Chondrocytes is Modulated by IL-1beta, TNF-Alpha and TGF-Beta. Osteoarthritis Cartilage (2006) 14:1163-73. doi: 10.1016/j.joca.2006.04.015

110. Boileau C, Amiable N, Martel-Pelletier J, Fahmi H, Duval N, Pelletier JP. Activation of Proteinase-Activated Receptor 2 in Human Osteoarthritic Cartilage Upregulates Catabolic and Proinflammatory Pathways Capable of Inducing Cartilage Degradation: A Basic Science Study. Arthritis Res Ther (2007) 9:R121. doi: 10.1186/ar2329

111. Ferrell WR, Kelso EB, Lockhart JC, Plevin R, McInnes IB. Protease-Activated Receptor 2: A Novel Pathogenic Pathway in a Murine Model of Osteoarthritis. Ann Rheum Dis (2010) 69:2051-4. doi: 10.1136/ard.2010.130336

112. Amiable N, Martel-Pelletier J, Lussier B, Kwan Tat S, Pelletier JP, Boileau C. Proteinase-Activated Receptor-2 Gene Disruption Limits the Effect of Osteoarthritis on Cartilage in Mice: A Novel Target in Joint Degradation. J Rheumatol (2011) 38:911-20. doi: 10.3899/jrheum.100710

113. Jackson MT, Moradi B, Zaki S, Smith MM, McCracken S, Smith SM, et al. Depletion of Protease-Activated Receptor 2 But Not Protease-Activated Receptor 1 may Confer Protection Against Osteoarthritis in Mice Through Extracartilaginous Mechanisms. Arthritis Rheumatol (2014) 66:3337-48. doi: $10.1002 /$ art. 38876

114. Huesa C, Ortiz AC, Dunning L, McGavin L, Bennett L, McIntosh K, et al. Proteinase-Activated Receptor 2 Modulates OA-Related Pain, Cartilage and Bone Pathology. Ann Rheum Dis (2016) 75:1989-97. doi: 10.1136/ annrheumdis-2015-208268

115. Huang X, Ni B, Xi Y, Chu X, Zhang R, You H. Protease-Activated Receptor 2 (PAR-2) Antagonist AZ3451 as a Novel Therapeutic Agent for Osteoarthritis. Aging (Albany NY) (2019) 11:12532-45. doi: 10.18632/aging.102586

116. Amin AR, Attur M, Patel RN, Thakker GD, Marshall PJ, Rediske J, et al. Superinduction of Cyclooxygenase-2 Activity in Human OsteoarthritisAffected Cartilage. Influence of Nitric Oxide. J Clin Invest (1997) 99:12317. doi: 10.1172/JCI119280

117. Johnston SA, Fox SM. Mechanisms of Action of Anti-Inflammatory Medications Used for the Treatment of Osteoarthritis. J Am Vet Med Assoc (1997) 210:1486-92. doi: 10.3354/dao029157

118. FitzGerald GA. COX-2 and Beyond: Approaches to Prostaglandin Inhibition in Human Disease. Nat Rev Drug Discov (2003) 2:879-90. doi: 10.1038/nrd1225

119. Miyamoto M, Ito H, Mukai S, Kobayashi T, Yamamoto H, Kobayashi M, et al. Simultaneous Stimulation of EP2 and EP4 is Essential to the Effect of Prostaglandin E2 in Chondrocyte Differentiation. Osteoarthritis Cartilage (2003) 11:644-52. doi: 10.1016/s1063-4584(03)00118-3

120. Clark CA, Schwarz EM, Zhang X, Ziran NM, Drissi H, O'Keefe RJ, et al. Differential Regulation of EP Receptor Isoforms During Chondrogenesis and 
Chondrocyte Maturation. Biochem Biophys Res Commun (2005) 328:764-76. doi: 10.1016/j.bbrc.2004.11.074

121. Aoyama T, Liang B, Okamoto T, Matsusaki T, Nishijo K, Ishibe T, et al. PGE2 Signal Through EP2 Promotes the Growth of Articular Chondrocytes. J Bone Miner Res (2005) 20:377-89. doi: 10.1359/JBMR.041122

122. Otsuka S, Aoyama T, Furu M, Ito K, Jin Y, Nasu A, et al. PGE2 Signal via EP2 Receptors Evoked by a Selective Agonist Enhances Regeneration of Injured Articular Cartilage. Osteoarthritis Cartilage (2009) 17:529-38. doi: 10.1016/ j.joca.2008.09.003

123. Tani Y, Sato M, Yokoyama M, Yokoyama M, Takahashi T, Toyoda E, et al. Intra-Articular Administration of EP2 Enhances the Articular Cartilage Repair in a Rabbit Model. J Tissue Eng Regener Med (2018) 12:2179-87. doi: $10.1002 /$ term. 2748

124. Mitsui H, Aoyama T, Furu M, Ito K, Jin Y, Maruyama T, et al. Prostaglandin E2 Receptor Type 2-Selective Agonist Prevents the Degeneration of Articular Cartilage in Rabbit Knees With Traumatic Instability. Arthritis Res Ther (2011) 13:R146. doi: 10.1186/ar3460

125. Sato T, Konomi K, Fujii R, Aono H, Aratani S, Yagishita N, et al. Prostaglandin EP2 Receptor Signalling Inhibits the Expression of Matrix Metalloproteinase 13 in Human Osteoarthritic Chondrocytes. Ann Rheum Dis (2011) 70:221-6. doi: 10.1136/ard.2009.118620

126. Attur M, Al-Mussawir HE, Patel J, Kitay A, Dave M, Palmer G, et al. Prostaglandin E2 Exerts Catabolic Effects in Osteoarthritis Cartilage: Evidence for Signaling via the EP4 Receptor. J Immunol (2008) 181:50828. doi: 10.4049/jimmunol.181.7.5082

127. Nishitani $\mathrm{K}$, Ito $\mathrm{H}$, Hiramitsu T, Tsutsumi R, Tanida S, Kitaori T, et al. PGE2 Inhibits MMP Expression by Suppressing MKK4-JNK MAP Kinase-C-JUN Pathway via EP4 in Human Articular Chondrocytes. J Cell Biochem (2010) 109:425-33. doi: 10.1002/jcb.22421

128. Southall MD, Vasko MR. Prostaglandin Receptor Subtypes, EP3C and EP4, Mediate the Prostaglandin E2-Induced cAMP Production and Sensitization of Sensory Neurons. J Biol Chem (2001) 276:16083-91. doi: 10.1074/jbc.M011408200

129. Yao C, Sakata D, Esaki Y, Li Y, Matsuoka T, Kuroiwa K, et al. Prostaglandin E2-EP4 Signaling Promotes Immune Inflammation Through Th1 Cell Differentiation and Th17 Cell Expansion. Nat Med (2009) 15:633-40. doi: $10.1038 / \mathrm{nm} .1968$

130. Chandrasekhar S, Yu XP, Harvey AK, Oskins JL, Lin C, Wang X, et al. Analgesic and Anti-Inflammatory Properties of Novel, Selective, and Potent EP4 Receptor Antagonists. Pharmacol Res Perspect (2017) 5:e00316. doi: $10.1002 /$ prp2.316

131. Chen H, Hu B, Lv X, Zhu S, Zhen G, Wan M, et al. Prostaglandin E2 Mediates Sensory Nerve Regulation of Bone Homeostasis. Nat Commun (2019) 10:181. doi: 10.1038/s41467-018-08097-7

132. Rausch-Derra LC, Huebner M, Rhodes L. Evaluation of the Safety of LongTerm, Daily Oral Administration of Grapiprant, a Novel Drug for Treatment of Osteoarthritic Pain and Inflammation, in Healthy Dogs. Am J Vet Res (2015) 76:853-9. doi: 10.2460/ajvr.76.10.853

133. Kirkby Shaw K, Rausch-Derra LC, Rhodes L. Grapiprant: An EP4 Prostaglandin Receptor Antagonist and Novel Therapy for Pain and Inflammation. Vet Med Sci (2016) 2:3-9. doi: 10.1002/vms3.13

134. Robertson-Plouch C, Stille JR, Liu P, Smith C, Brown D, Warner M, et al. A Randomized Clinical Efficacy Study Targeting Mpges1 or EP4 in Dogs With Spontaneous Osteoarthritis. Sci Transl Med (2019) 11:eaaw9993. doi: $10.1126 /$ scitranslmed.aaw9993

135. Jiao K, Niu LN, Li QH, Ren GT, Zhao CM, Liu YD, et al. Beta2-Adrenergic Signal Transduction Plays a Detrimental Role in Subchondral Bone Loss of Temporomandibular Joint in Osteoarthritis. Sci Rep (2015) 5:12593. doi: $10.1038 /$ srep 12593

136. Jiao K, Zeng G, Niu LN, Yang HX, Ren GT, Xu XY, et al. Activation of Alpha2a-Adrenergic Signal Transduction in Chondrocytes Promotes Degenerative Remodelling of Temporomandibular Joint. Sci Rep (2016) 6:30085. doi: 10.1038/srep30085

137. Lorenz J, Schafer N, Bauer R, Jenei-Lanzl Z, Springorum RH, Grassel S. Norepinephrine Modulates Osteoarthritic Chondrocyte Metabolism and Inflammatory Responses. Osteoarthritis Cartilage (2016) 24:325-34. doi: 10.1016/j.joca.2015.08.007

138. Sondergaard BC, Wulf H, Henriksen K, Schaller S, Oestergaard S, Qvist P, et al. Calcitonin Directly Attenuates Collagen Type II Degradation by
Inhibition of Matrix Metalloproteinase Expression and Activity in Articular Chondrocytes. Osteoarthritis Cartilage (2006) 14:759-68. doi: 10.1016/j.joca.2006.01.014

139. Katri A, Dabrowska A, Lofvall H, Karsdal MA, Andreassen KV, Thudium CS, et al. A Dual Amylin and Calcitonin Receptor Agonist Inhibits Pain Behavior and Reduces Cartilage Pathology in an Osteoarthritis Rat Model. Osteoarthritis Cartilage (2019) 27:1339-46. doi: 10.1016/j.joca.2019.05.016

140. Suri S, Gill SE, Massena de Camin S, Wilson D, McWilliams DF, Walsh DA. Neurovascular Invasion at the Osteochondral Junction and in Osteophytes in Osteoarthritis. Ann Rheum Dis (2007) 66:1423-8. doi: 10.1136/ard.2006.063354

141. Ikeuchi M, Wang Q, Izumi M, Tani T. Nociceptive Sensory Innervation of the Posterior Cruciate Ligament in Osteoarthritic Knees. Arch Orthop Trauma Surg (2012) 132:891-5. doi: 10.1007/s00402-012-1478-7

142. Mapp PI, Walsh DA. Mechanisms and Targets of Angiogenesis and Nerve Growth in Osteoarthritis. Nat Rev Rheumatol (2012) 8:390-8. doi: 10.1038/ nrrheum.2012.80

143. Aso K, Izumi M, Sugimura N, Okanoue Y, Ushida T, Ikeuchi M. Nociceptive Phenotype Alterations of Dorsal Root Ganglia Neurons Innervating the Subchondral Bone in Osteoarthritic Rat Knee Joints. Osteoarthritis Cartilage (2016) 24:1596-603. doi: 10.1016/j.joca.2016.04.009

144. Zhu S, Zhu J, Zhen G, Hu Y, An S, Li Y, et al. Subchondral Bone Osteoclasts Induce Sensory Innervation and Osteoarthritis Pain. J Clin Invest (2019) 129:1076-93. doi: 10.1172/JCI121561

145. Bullock CM, Wookey P, Bennett A, Mobasheri A, Dickerson I, Kelly S. Peripheral Calcitonin Gene-Related Peptide Receptor Activation and Mechanical Sensitization of the Joint in Rat Models of Osteoarthritis Pain. Arthritis Rheumatol (2014) 66:2188-200. doi: 10.1002/art.38656

146. de Crombrugghe B, Lefebvre V, Nakashima K. Regulatory Mechanisms in the Pathways of Cartilage and Bone Formation. Curr Opin Cell Biol (2001) 13:721-7. doi: 10.1016/s0955-0674(00)00276-3

147. Bergwitz C, Juppner H. Regulation of Phosphate Homeostasis by PTH, Vitamin D, and FGF23. Annu Rev Med (2010) 61:91-104. doi: 10.1146/ annurev.med.051308.111339

148. Wein MN, Kronenberg HM. Regulation of Bone Remodeling by Parathyroid Hormone. Cold Spring Harb Perspect Med (2018) 8:a031237. doi: 10.1101/ cshperspect.a031237

149. Guo J, Chung UI, Kondo H, Bringhurst FR, Kronenberg HM. The PTH/ PTHrP Receptor can Delay Chondrocyte Hypertrophy In Vivo Without Activating Phospholipase C. Dev Cell (2002) 3:183-94. doi: 10.1016/s15345807(02)00218-6

150. Panda D, Goltzman D, Juppner H, Karaplis AC. TIP39/parathyroid Hormone Type 2 Receptor Signaling is a Potent Inhibitor of Chondrocyte Proliferation and Differentiation. Am J Physiol Endocrinol Metab (2009) 297: E1125-1136. doi: 10.1152/ajpendo.00254.2009

151. Terkeltaub R, Lotz M, Johnson K, Deng D, Hashimoto S, Goldring MB, et al. Parathyroid Hormone-Related Proteins is Abundant in Osteoarthritic Cartilage, and the Parathyroid Hormone-Related Protein 1-173 Isoform is Selectively Induced by Transforming Growth Factor Beta in Articular Chondrocytes and Suppresses Generation of Extracellular Inorganic Pyrophosphate. Arthritis Rheumatol (1998) 41:2152-64. doi: 10.1002/15290131(199812)41:12<2152::AID-ART10>3.0.CO;2-X

152. Sampson ER, Hilton MJ, Tian Y, Chen D, Schwarz EM, Mooney RA, et al. Teriparatide as a Chondroregenerative Therapy for Injury-Induced Osteoarthritis. Sci Transl Med (2011) 3:101ra193. doi: 10.1126/scitranslmed. 3002214

153. Kong D, Guan Q, Li G, Xin W, Qi X, Guo Y, et al. Expression of FSHR in Chondrocytes and the Effect of FSH on Chondrocytes. Biochem Biophys Res Commun (2018) 495:587-93. doi: 10.1016/j.bbrc.2017.11.053

154. Wu Y, Wu T, Xu B, Xu X, Chen H, Li X. Oxytocin Prevents Cartilage Matrix Destruction via Regulating Matrix Metalloproteinases. Biochem Biophys Res Commun (2017) 486:601-6. doi: 10.1016/j.bbrc.2017.02.115

155. Cai HQ, Miao MY, Zhang WL. AT1/2R Affects the Proliferation and Apoptosis of Chondrocytes Induced by Oxygen-Glucose Deprivation. Bratisl Lek Listy (2020) 121:584-8. doi: 10.4149/BLL_2020_097

156. Kaneva MK, Kerrigan MJ, Grieco P, Curley GP, Locke IC, Getting SJ. Chondroprotective and Anti-Inflammatory Role of Melanocortin Peptides in TNF-Alpha Activated Human C-20/A4 Chondrocytes. Br J Pharmacol (2012) 167:67-79. doi: 10.1111/j.1476-5381.2012.01968.x 
157. Lorenz J, Seebach E, Hackmayer G, Greth C, Bauer RJ, Kleinschmidt K, et al. Melanocortin 1 Receptor-Signaling Deficiency Results in an Articular Cartilage Phenotype and Accelerates Pathogenesis of Surgically Induced Murine Osteoarthritis. PloS One (2014) 9:e105858. doi: 10.1371/ journal.pone.0105858

158. Chen J, Xie JJ, Shi KS, Gu YT, Wu CC, Xuan J, et al. Glucagon-Like Peptide-1 Receptor Regulates Endoplasmic Reticulum Stress-Induced Apoptosis and the Associated Inflammatory Response in Chondrocytes and the Progression of Osteoarthritis in Rat. Cell Death Dis (2018) 9:212. doi: 10.1038/s41419017-0217-y

159. Khatib AM, Lomri A, Moldovan F, Soliman H, Fiet J, Mitrovic DR. Endothelin 1 Receptors, Signal Transduction and Effects on DNA and Proteoglycan Synthesis in Rat Articular Chondrocytes. Cytokine (1998) 10:669-79. doi: 10.1006/cyto.1998.0347

160. Zhang M, Yang H, Wan X, Lu L, Zhang J, Zhang H, et al. Prevention of Injury-Induced Osteoarthritis in Rodent Temporomandibular Joint by Targeting Chondrocyte CaSR. J Bone Miner Res (2019) 34:726-38. doi: $10.1002 / j b m r .3643$

161. Mao D, Wu M, Wei J, Zhou X, Yang L, Chen F. MicroRNA-101a-3p Could be Involved in the Pathogenesis of Temporomandibular Joint Osteoarthritis by Mediating UBE2D1 and FZD4. J Oral Pathol Med (2021) 50:236-43. doi: 10.1111 /jop.13131

162. Bileviciute-Ljungar I, Saxne T, Spetea M. Anti-Inflammatory Effects of Contralateral Administration of the Kappa-Opioid Agonist U-50,488H in Rats With Unilaterally Induced Adjuvant Arthritis. Rheumatol (Oxford) (2006) 45:295-302. doi: 10.1093/rheumatology/kei156

163. Wu L, Zhang S, Shkhyan R, Lee S, Gullo F, Eliasberg CD, et al. Kappa Opioid Receptor Signaling Protects Cartilage Tissue Against Posttraumatic Degeneration. JCI Insight (2017) 2:e88553. doi: 10.1172/ jci.insight. 88553

164. Geborek P, Saxne T, Pettersson H, Wollheim FA. Synovial Fluid Acidosis Correlates With Radiological Joint Destruction in Rheumatoid Arthritis Knee Joints. J Rheumatol (1989) 16:468-72.

165. Konttinen YT, Mandelin J, Li TF, Salo J, Lassus J, Liljestrom M, et al. Acidic Cysteine Endoproteinase Cathepsin K in the Degeneration of the Superficial Articular Hyaline Cartilage in Osteoarthritis. Arthritis Rheumatol (2002) 46:953-60. doi: 10.1002/art.10185

166. Razaq S, Wilkins RJ, Urban JP. The Effect of Extracellular $\mathrm{pH}$ on Matrix Turnover by Cells of the Bovine Nucleus Pulposus. Eur Spine J (2003) 12:341-9. doi: 10.1007/s00586-003-0582-3

167. Holzer P. Acid-Sensitive Ion Channels and Receptors. Handb Exp Pharmacol (2009) 194:283-332. doi: 10.1007/978-3-540-79090-7_9

168. Yuan FL, Chen FH, Lu WG, Li X, Wu FR, Li JP, et al. Acid-Sensing Ion Channel 1a Mediates Acid-Induced Increases in Intracellular Calcium in Rat Articular Chondrocytes. Mol Cell Biochem (2010) 340:153-9. doi: 10.1007/ s11010-010-0412-y

169. Li R, Guan ZJ, Bi SY, He L, Niu X, You Y, et al. The Proton-Activated G Protein-Coupled Receptor GPR4 Regulates the Development of Osteoarthritis via Modulating CXCL12/CXCR7 Signaling. Cell Death Dis (2021). doi: 10.1038/s41419-021-04455-4
170. Sueishi T, Akasaki Y, Goto N, Kurakazu I, Toya M, Kuwahara M, et al. GRK5 Inhibition Attenuates Cartilage Degradation via Decreased NF-kappaB Signaling. Arthritis Rheumatol (2020) 72:620-31. doi: 10.1002/art.41152

171. Carlson EL, Karuppagounder V, Pinamont WJ, Yoshioka NK, Ahmad A, Schott EM, et al. Paroxetine-Mediated GRK2 Inhibition Is a DiseaseModifying Treatment for Osteoarthritis. Sci Transl Med (2021) 13: eaau8491. doi: 10.1126/scitranslmed.aau8491

172. Spychala J, Kitajewski J. Wnt and Beta-Catenin Signaling Target the Expression of Ecto-5'-Nucleotidase and Increase Extracellular Adenosine Generation. Exp Cell Res (2004) 296:99-108. doi: 10.1016/j.yexcr.2003.11.001

173. Costa MA, Barbosa A, Neto E, Sa-e-Sousa A, Freitas R, Neves JM, et al. On the Role of Subtype Selective Adenosine Receptor Agonists During Proliferation and Osteogenic Differentiation of Human Primary Bone Marrow Stromal Cells. JCell Physiol (2011) 226:1353-66. doi: 10.1002/jcp.22458

174. Geiger BC, Wang S, Padera RF Jr, Grodzinsky AJ, Hammond PT. CartilagePenetrating Nanocarriers Improve Delivery and Efficacy of Growth Factor Treatment of Osteoarthritis. Sci Transl Med (2018) 10:eaat8800. doi: $10.1126 /$ scitranslmed.aat8800

175. Chen Y, Shen W, Tang C, Huang J, Fan C, Yin Z, et al. Targeted Pathological Collagen Delivery of Sustained-Release Rapamycin to Prevent Heterotopic Ossification. Sci Adv (2020) 6:eaay9526. doi: 10.1126/sciadv.aay9526

176. Ji ML, Jiang H, Wu F, Geng R, Ya LK, Lin YC, et al. Precise Targeting of miR141/200c Cluster in Chondrocytes Attenuates Osteoarthritis Development. Ann Rheum Dis (2020) 0:1-11. doi: 10.1136/annrheumdis-2020-218469

177. Kwon H, Brown WE, Lee CA, Wang D, Paschos N, Hu JC, et al. Surgical and Tissue Engineering Strategies for Articular Cartilage and Meniscus Repair. Nat Rev Rheumatol (2019) 15:550-70. doi: 10.1038/s41584-019-0255-1

178. Xing D, Liu W, Li JJ, Liu L, Guo A, Wang B, et al. Engineering 3D Functional Tissue Constructs Using Self-Assembling Cell-Laden Microniches. Acta Biomater (2020) 114:170-82. doi: 10.1016/j.actbio.2020.07.058

179. Yuan C, Pan Z, Zhao K, Li J, Sheng Z, Yao X, et al. Classification of Four Distinct Osteoarthritis Subtypes With a Knee Joint Tissue Transcriptome Atlas. Bone Res (2020) 8:38. doi: 10.1038/s41413-020-00109-x

Conflict of Interest: The authors declare that the research was conducted in the absence of any commercial or financial relationships that could be construed as a potential conflict of interest.

Publisher's Note: All claims expressed in this article are solely those of the authors and do not necessarily represent those of their affiliated organizations, or those of the publisher, the editors and the reviewers. Any product that may be evaluated in this article, or claim that may be made by its manufacturer, is not guaranteed or endorsed by the publisher.

Copyright (c) 2022 Wang, Liu, Wang and Luo. This is an open-access article distributed under the terms of the Creative Commons Attribution License (CC BY). The use, distribution or reproduction in other forums is permitted, provided the original author(s) and the copyright owner(s) are credited and that the original publication in this journal is cited, in accordance with accepted academic practice. No use, distribution or reproduction is permitted which does not comply with these terms. 